\title{
Apparent Accumulated Nitrogen Fertilizer Recovery in Long-Term Wheat-Maize Cropping Systems in China
}

\author{
Jie Liu ${ }^{1,2}$, Jumei $\mathrm{Li}^{2}$, Yibing Ma ${ }^{2,3, *}$, Yuehui Jia ${ }^{1}$ and Qiong Liang ${ }^{1}$ \\ 1 College of Plant Science and Technology, Beijing University of Agriculture, Beijing 102206, China; \\ jiel@bua.edu.cn (J.L.); yhjia@bua.edu.cn (Y.J.); liangqiong84@163.com (Q.L.) \\ 2 Ministry of Agriculture Key Laboratory of Plant Nutrition and Nutrient Cycling, Institute of Agricultural \\ Resources and Regional Planning, Chinese Academy of Agricultural Sciences, Beijing 100081, China; \\ lijumei@caas.cn \\ 3 School of Resources and Environment, University of Jinan, Jinan 250022, China \\ * Correspondence: ybma@caas.ac.cn; Tel.: +86-10-8210-6201; Fax: +86-10-8210-6225
}

Received: 25 October 2018; Accepted: 30 November 2018; Published: 4 December 2018

\begin{abstract}
Recovery efficiency of nitrogen fertilizers has always been an important issue, especially for $\mathrm{N}$ fertilizer recommendation rate in cropping systems. Based on the equilibrium of $\mathrm{N}$ in the soil-plant system, apparent accumulated $\mathrm{N}$ fertilizer recovery $\left(\mathrm{NRE}_{\mathrm{ac}}\right)$ was determined for long-term (15-years) experiments in wheat (Triticum aestivum L.) and maize (Zea mays L.) rotations at five field sites with various soils and climate characteristics in China. The result showed that the frequency of cropping and the content of soil clay affected $\mathrm{NRE}_{\mathrm{ac}}$ positively and negatively, respectively. In the absence of nutrient deficiencies and other soil constraints (from NPK (nitrogen, phosphorus and potassium) in S2-CP (site2-Changping) in Beijing, S3-ZZ (site3-Zhengzhou) in Henan province and S4-YL (site4-Yangling) in Shaanxi province), $\mathrm{NRE}_{\mathrm{ac}}$ had a narrow range from $70 \%$ to $78 \%$ with the highest average of $75 \%$ in wheat and maize cropping system. Meanwhile, the value $75 \%$ of $\mathrm{NER}_{\mathrm{ac}}$ is a rational value proved by 3414 experiments. Additionally, the nitrate-N approach suggested that nitrate- $\mathrm{N}$ could be utilized by subsequent crops, the amount of which is calculated by the equation $-1.23 \times\left[\left(\mathrm{NO}_{3}{ }^{-}-\mathrm{N}\right)-87\right]$. Furthermore, another simpler and feasible method was proposed to maintain basic soil fertility while achieving a rational grain yield and maintaining a safe environmental upper threshold of nitrate. The present study provided a suit of methods for $\mathrm{N}$ fertilizer recommendations for the optimization of $\mathrm{N}$ applications in wheat and maize cropping system in China.
\end{abstract}

Keywords: apparent $\mathrm{N}$ recovery efficiency; fertilizer recommendation; wheat; maize

\section{Introduction}

The recovery efficiency of $\mathrm{N}$ fertilizers applied to crops $\left(\mathrm{RE}_{\mathrm{N}}\right.$ : the ratio of total $\mathrm{N}$ uptake by aboveground plant dry matter to the amount of fertilizer-N applied) has always been an important issue due to opposing goals [1]. On the one hand global food security must keep pace with an increasing world population, but at the same time there are legitimate concerns about environmental pollution caused by excess $\mathrm{N}$ applied to crops [1,2]. It is estimated that food demand will rapidly increase to $2.8 \times 10^{9} \mathrm{t}$ in 2030 and the corresponding consumption of fertilizer- $\mathrm{N}$ is predicted to be $9.6 \times 10^{7} \mathrm{t}$ compared with $7.8 \times 10^{7} \mathrm{t}$ year $^{-1}$ in $1995 / 1997$ worldwide [3]. Especially in China, the total consumption of fertilizer- $N$ has increased from $0.93 \times 10^{7} \mathrm{t}$ in 1980 to $2.39 \times 10^{7} \mathrm{t}$ in 2013 [4]. Fixen and West [5] reported that fertilizer-N supplies basic food needs for at least $40 \%$ of the global population and estimated that at least $60 \%$ of humanity will eventually owe its nutritional survival to 
fertilizer in the future. On the other hand, Chinese farmers always apply excess fertilizer- $\mathrm{N}$ to crops expecting to produce maximum yield. It is estimated that only $30-50 \%$ of applied $\mathrm{N}$ fertilizers are taken up by crops worldwide [6]. In China, Fixen and West [5] documented that $\mathrm{AE}_{\mathrm{N}}$ (agronomic $\mathrm{N}$ use efficiency: $\mathrm{kg}$ grain per $\mathrm{kg}$ fertilizer-N) decreased from approximately 10-15 during 1958-1963 to 10 during 1981-1983 for wheat, and from 20-30 to 13.4 for maize. Consequently, environmental pollution due to excess $\mathrm{N}$ applied to crops is gradually becoming serious and a major cause for concern. Nitrate pollution in groundwater is one of the major pollution problems which have been reported in many countries such as the UK, Denmark, Belgium, France and India [7].

The need for food security and environmental protection is the paradox for fertilizer-N use [8,9]. Thus, a balancing between grain yield and the risk of nitrate- $\mathrm{N}$ loss is a common aim for both agronomists and environmentalists. Changes of $\mathrm{RE}_{\mathrm{N}}$, yield and soil $\mathrm{NO}_{3}{ }^{-}-\mathrm{N}$ accumulation were subject to external factors, such as rate, place and time of applied $\mathrm{N}$ fertilizers, etc. As a result, Benbi and Biswas [10] reported that $\mathrm{RE}_{\mathrm{N}}$ varied from 25 to $90 \%$ for both maize and wheat, which provided a possibility for mediating the paradox by improving fertilizer- $\mathrm{N}$ recommendation. The rate of $\mathrm{N}$ applied in the field was initially based on the theory of target yield fertilizer recommendation reported by Truog [11], and gradually improved with its widespread application [12-17], where determination of $\mathrm{RE}_{\mathrm{N}}$ is the key. At present there are two methods, the difference and ${ }^{15} \mathrm{~N}$ isotopic methods, to estimate $\mathrm{RE}_{\mathrm{N}}$ [18]. However, both methods have some assumptions. The former assumes that soil $\mathrm{N}$ uptake by the crop is the same for both fertilized and unfertilized $N$ treatments, while the latter assumes that the isotope composition of the tracer is constant, soil microbial populations make no distinction between the ${ }^{14} \mathrm{~N}$ and ${ }^{15} \mathrm{~N}$ isotopes, and the chemical identities of isotopes are maintained in biochemical systems. In general, the value determined by the former is lower than the latter on soils with higher available $\mathrm{N}$, and the former is higher than the latter on soils with lower available $\mathrm{N}$, which the elusive soil nitrogen-supplying capacity could account for. Unfortunately, approaches to measure $\mathrm{RE}_{\mathrm{N}}$ are not widely accepted across a wide range of soils [19-21].

Therefore, a feasible method to estimate $\mathrm{RE}_{\mathrm{N}}$ is an agenda for fertilizer- $\mathrm{N}$ recommendation, especially in wheat-maize cropping system in China, which is a dominant cropping system with excessive $\mathrm{N}$ rate and high level of residual soil nitrate- $\mathrm{N}$ [22]. Accordingly, a long-term experiment of national soil fertility and fertilizers in wheat-maize cropping system was used in the present study. The objectives were to: (i) discuss the factors affected $\mathrm{NRE}_{\mathrm{ac}}\left(\mathrm{NRE}_{\mathrm{ac}}\right.$ : apparent accumulated $\mathrm{N}$ recovery efficiency); (ii) determine $\mathrm{NRE}_{\mathrm{ac}}$ on the condition of nitrogen equilibrium in the soil-plant system [23,24]; (iii) further complete target yield $\mathrm{N}$ recommendation with regulating the relationship between $\mathrm{N}$ fertilization and utilization of soil $\mathrm{NO}_{3}{ }^{-}-\mathrm{N}$ in the wheat-maize cropping system in China.

\section{Materials and Methods}

The data involved in this study was derived from a network of experiments in China, which was set up in 1990 to determine the response of crops to fertilizers on various types of soil under different climatic conditions. The study was composed of five sites, distributed in five districts: Urumqi (in Xinjiang province, icon S1-WQ), Changping (in Beijing, icon S2-CP), Zhengzhou (in Henan province, icon S3-ZZ), Yangling (in Shaanxi province, icon S4-YL) and Qiyang (in Hunan province, icon S5-QY), which dominate soils and climates of wheat and maize growing regions in China. Initial properties of soils are briefly listed in Table 1 and more details can be found in Liu [25]. 
Table 1. The experiment sites and initial properties.

\begin{tabular}{|c|c|c|c|c|c|}
\hline & Sites & & & & \\
\hline Items & S1-WQ & S2-CP & S3-ZZ & S4-YL & S5-QY \\
\hline Location & Wulumuqi, Xinjiang & Changping, Beijing & Zhengzhou, Henan & Yangling, Shaanxi & Qiyang, Hunan \\
\hline Longitude & $87^{\circ} 25^{\prime} 58^{\prime \prime} \mathrm{E}$ & $116^{\circ} 12^{\prime} 08^{\prime \prime} \mathrm{E}$ & $113^{\circ} 39^{\prime} 25^{\prime \prime} \mathrm{E}$ & $108^{\circ} 03^{\prime} 54^{\prime \prime} \mathrm{E}$ & $111^{\circ} 52^{\prime} 32^{\prime \prime} \mathrm{E}$ \\
\hline Latitude & $43^{\circ} 58^{\prime} 23^{\prime \prime} \mathrm{N}$ & $40^{\circ} 12^{\prime} 34^{\prime \prime} \mathrm{N}$ & $34^{\circ} 47^{\prime} 02^{\prime \prime} \mathrm{N}$ & $34^{\circ} 16^{\prime} 49^{\prime \prime} \mathrm{N}$ & $26^{\circ} 45^{\prime} 12^{\prime \prime} \mathrm{N}$ \\
\hline Mean annual temperature, ${ }^{\circ} \mathrm{C}$ & 7.4 & 11.8 & 14.2 & 12.7 & 18.3 \\
\hline Annual rainfall, $\mathrm{mm}$ & 247 & 577 & 644 & 542 & 1276 \\
\hline Cropping, per year & wheat or maize & wheat-maize & wheat-maize & wheat-maize & wheat-maize \\
\hline Soil classification in China & Grey desert soil & Fluvo-aquic soil & Fluvo-aquic soil & Loessial soil & Red earth \\
\hline Soil classification in FAO & Calcaric Cambisol & Haplic Luvisol & Calcaric Cambisol & Calcaric Regosol & Eutric Cambisol \\
\hline Sand/Silt/Clay (\%) & $18.5 / 53.2 / 28.3$ & $20.3 / 65.0 / 14.7$ & $26.5 / 60.7 / 12.8$ & $31.6 / 51.6 / 16.8$ & $3.7 / 34.9 / 61.4$ \\
\hline Soil pH (water $/$ soil = 2.5) & 8.1 & 8.2 & 8.3 & 8.6 & 5.7 \\
\hline Organic carbon $\left(\mathrm{g} \mathrm{kg}^{-1}\right)$ & 8.8 & 7.1 & 6.7 & 6.3 & 6.7 \\
\hline Total N $\left(\mathrm{g} \mathrm{kg}^{-1}\right)$ & 0.87 & 0.64 & 1.01 & 0.83 & 1.07 \\
\hline Total $\mathrm{P}\left(\mathrm{g} \mathrm{kg}^{-1}\right)$ & 0.67 & 0.69 & 0.65 & 0.61 & 0.45 \\
\hline Total K $\left(\mathrm{g} \mathrm{kg}^{-1}\right)$ & 23 & 14.6 & 16.9 & 22.8 & 13.7 \\
\hline
\end{tabular}


The present study included two cropping systems, one crop of wheat or maize per year in S1-WQ, another wheat-maize rotation per year at the other four sites. All experiments were unreplicated in a randomized design due to pressure on experiment land, where plot size varied between 100 and $468 \mathrm{~m}^{2}$. Each experiment consisted of the following nine treatments: (1) CK (unfertilized), (2) PK (phosphorus and potassium), (3) N (nitrogen), (4) NK (nitrogen plus potassium), (5) NP (nitrogen plus phosphorus), (6) NPK (nitrogen, phosphorus plus potassium, (7) FS (NPK plus straw), (8) FM (NPK plus manure) and (9) HF (high NPK plus straw). Rates of fertilizers are shown in Liu et al. [25], in which the rates of manures or straw were based on $\mathrm{N}$ concentration, ratio of $\mathrm{N}$ from fertilizer to from manures or straws is 7:3, and the amounts of $\mathrm{P}$ and $\mathrm{K}$ were computed by $\mathrm{P}$ and $\mathrm{K}$ concentrations multiplied by the rates of applied manures or straw, respectively. Manures were applied after composting and straw was derived from corresponding treatments. All straw or manures were applied once-yearly as soon as the crop (wheat or maize) was harvested in S1-WQ, or wheat was harvested at the other four sites. The sources of N, P and K were urea, superphosphate and potassium chloride, respectively. Half of the $\mathrm{N}$ and all of the $\mathrm{P}$ and $\mathrm{K}$ were applied as basal fertilizer. The remainder of the $\mathrm{N}$ was applied as topdressing when needed. Irrigation was adjusted to annual precipitation when needed. When necessary, weeding by hand and pesticide applications were implemented.

\subsection{Sampling and Analysis}

Crops were harvested manually close to the ground with sickles at maturity and totally removed from the plots. Grain and straw were laid out in the sun on concrete slabs before threshing and then oven-dried at $65{ }^{\circ} \mathrm{C}$ to uniform moisture level before weighed, and then ground to pass a $0.15-\mathrm{cm}$ sieve and stored for analysis. Plant samples to be tested were from the center of the plot in order to minimize marginal effects.

Soil samples were collected from the plough layer $(0-20 \mathrm{~cm})$ at the start of the experiment and between crop harvest and fertilizer application each autumn. At least five cores in each plot of each site were taken with a $5-\mathrm{cm}$ diameter auger. Cores from the same plot were mixed thoroughly and air-dried, ground to pass through a 2.0-mm sieve and stored for analysis.

Plant samples were analyzed for total nitrogen using the micro-Kjeldahl digestion method, while soil samples were analyzed for total nitrogen, total phosphorus and total potassium using micro-Kjeldahl digestion, colorimetric analysis and a dissolution-flame photometer, respectively [26].

\subsection{Calculation and Statistical Analysis}

Based on mass balance theory, apparent accumulated $\mathrm{N}$ recovery efficiency ( $\mathrm{NRE}_{\mathrm{ac}} \%$ ) was calculated as total $\mathrm{N}$ uptake $\left(\mathrm{N}_{\mathrm{p}}\right.$, in $\mathrm{kg} \mathrm{ha}^{-1}$ ) by crops (grain and straw) divided by total $\mathrm{N}$ rate $\left(\mathrm{N}_{\mathrm{f}}\right.$, in $\left.\mathrm{kg} \mathrm{ha}^{-1}\right)$ using the following equation:

$$
\mathrm{NRE}_{\mathrm{ac}} \%=\frac{\sum_{\mathrm{i}=1}^{\mathrm{i}=\mathrm{n}} \mathrm{N}_{\mathrm{pi}}}{\sum_{\mathrm{i}=1}^{\mathrm{i}=\mathrm{n}} \mathrm{N}_{\mathrm{fi}}} \times 100
$$

where $i$ is the number of cultivation years and the maximum value of $n$ is 15 years in the present study. $\mathrm{Np}$ has been calculated in the companion paper [25] using the following equation:

$$
\mathrm{N}_{\mathrm{P}}=\text { Yield }_{\text {wheat }} \times 2.73 \%+\text { Yield }_{\text {maize }} \times 2.21 \%
$$

where Yield ${ }_{\text {wheat }}$ and Yield $\mathrm{d}_{\text {maize }}$ represent the grain yields of wheat and maize $\left(\mathrm{kg} \mathrm{ha}^{-1}\right)$, respectively, and $2.73 \%$ and $2.21 \%$ were the corresponding $\mathrm{N}$ concentrations in the aboveground biomass of wheat and maize, respectively. Moreover, on the principle of yield-based $\mathrm{N}$ recommendations [12,27], the following equation was used to compute a recommended $\mathrm{N}$ rate:

$$
\mathrm{N}_{\text {f.opt }}=\frac{\mathrm{N}_{\mathrm{p}}}{\text { NRE }_{\text {ac.opt }} \%}
$$

where $\mathrm{NRE}_{\mathrm{ac} . o p t}$ is an optimal $\mathrm{NRE}_{\mathrm{ac}}$ with application of an economically optimal $\mathrm{N}$ rate $\left(\mathrm{N}_{\text {f.opt }}\right)$. In the present study, $\mathrm{NRE}_{\mathrm{ac} . \mathrm{opt}}$ is the average of $\mathrm{NRE}_{\mathrm{ac}}$ from NPK treatment in S2-CP, S3-YL and S4-ZZ, and the value is $75 \%$. 
In order to assess the reliability of $\mathrm{N}$ rate recommended by Equation (3), the experiment with ' $3414 w$ design was introduced into the present study, which is one of D-optimal design for quadratic regression [28]. In the experiment of '3414' design, 3 represents 3 factors (nitrogen, phosphorus and potassium), 4 represents 4 rates of factors $(0,50 \%$ normal rate, normal rate and $150 \%$ normal rate), and 14 represents 14 treatments. Since 2005, the "3414" experiment was carried out nationwide that is a standard method for fertilizer recommendation in China [29]. Four of the 14 treatments were selected in the present study and they were N0P2K2, N1P2K2, N2P2K2 and N3P2K2, where N0, N1, N2 and N3 represent nitrogen rates and $\mathrm{P} 2$ and $\mathrm{K} 2$ represent appropriate phosphorus and potassium rates in the locality, respectively. More details are shown in Appendix A and Appendix References. A quadratic curve fitted the data was as follows:

$$
\text { Yield }=\mathrm{a} \times \mathrm{N}_{\mathrm{f}}^{2}+\mathrm{b} \times \mathrm{N}_{\mathrm{f}}+\text { Yield }_{0}
$$

where Yield is grain yield $\left(\mathrm{kg} \mathrm{ha}^{-1}\right), \mathrm{N}_{\mathrm{f}}$ is the rate of applied $\mathrm{N}$, Yield $\mathrm{d}_{0}$ is an intercept, defined as a basic grain yield $\left(\mathrm{kg} \mathrm{ha}^{-1}\right)$ without applied $\mathrm{N}$, a and $\mathrm{b}$ are two coefficients.

$\mathrm{N}_{\text {f.opt }}$ is reached when

$$
\frac{\partial \text { Yield }}{\partial \mathrm{N}_{\mathrm{f}}}=2 \mathrm{aN}_{\mathrm{f} . \mathrm{opt}}+\mathrm{b}=\mathrm{P}
$$

where $\mathrm{P}$ equals the ratio of the cost of $1 \mathrm{~kg}$ fertilizer $\mathrm{N}$ to the price of $1 \mathrm{~kg}$ grain yield, and there are $2.33( \pm 0.28)$ and $2.76( \pm 0.50)$ for wheat and maize, respectively in the present study [30] and the variance of $\mathrm{P}$ does not make sense to the results of the study. Therefore, $\mathrm{N}_{\mathrm{f} . \mathrm{opt}}$ was calculated by the following equation:

$$
\text { wheat }: \mathrm{N}_{\text {f.opt }}=\frac{2.33-\mathrm{b}}{2 \mathrm{a}} ; \text { maize }: \mathrm{N}_{\text {f.opt }}=\frac{2.76-\mathrm{b}}{2 \mathrm{a}}
$$

Based on the ' 3414 ' design and Equations (4) and (6), the following equation fitted the relationship between Yield opt $_{\text {and }}$ Yield 0 :

$$
\text { Yield }_{\text {opt }}=\alpha \times \text { Yield }_{0}
$$

where Yield ${ }_{\text {opt }}$ is a grain yield at $\mathrm{N}_{\text {f.opt }}$ and $\alpha$ is a coefficient.

Statistical analyses were performed using SPSS analytical software (SPSS Inc., Chicago, IL, USA; version 19). Linear regression was used to determine the relationship between $\mathrm{N}_{\text {f.opt }}$ with estimatied by $\mathrm{NRE}_{\mathrm{ac}}$ and measured in "3414" experiments, and correlation between yield opt $_{\text {and }}$ yield $_{0}$. A quadratic curve regression was used to fit the response of yield to $\mathrm{N}$ application in " 3414 " experiments. Analysis of variance (ANOVA) was used to test the differences of $\mathrm{NRE}_{\mathrm{ac}} \%$ among treatments and experiment sites.

\section{Results}

\subsection{Factors Affecting $N R E_{a c}$}

Apparent accumulated nitrogen recovery efficiencies $\left(\mathrm{NRE}_{\mathrm{ac}}\right)$ for the whole years of cultivation (15 years) are shown in Table 2. Values of $\mathrm{NRE}_{\mathrm{ac}}$ for all treatments have a wide variation that ranged from 24 to 161\%. Except all treatments in S5-QY and S1-WQ1 during 1991-1994, and N in S2-CP and $\mathrm{S} 4-\mathrm{YL}, \mathrm{NRE}_{\mathrm{ac}}$ from the same treatment were always higher in the wheat-maize rotation per year (in S2-CP, S3-ZZ and S4-YL) than in the wheat-maize-maize rotation per 3 years (in S1-WQ2). And averages of the former were 40, 46, 71, 75, 62, 71 and 62 for N, NK, NP, NPK, FS, FM and HF treatments, respectively. When comparing $\mathrm{NRE}_{\mathrm{ac}}$ among treatments combined application of $\mathrm{N}, \mathrm{P}$ and $\mathrm{K}$ in all experimental sites, there were also discrepancies. NRE $\mathrm{ac}_{\mathrm{c}}$ from the NPK treatment were always higher than that from incomplete nutrients treatments, in which the values from NP were the highest followed by that from NK and $\mathrm{N}$ in all experiment sites (except from $\mathrm{N}$ and $\mathrm{NK}$ in S1-WQ2). Especially, $\mathrm{NRE}_{\mathrm{ac}}$ from NPK was significant higher in S1-WQ1 with lower N input than in S1-WQ2 with normal $\mathrm{N}$ input. There were no significant differences among $\mathrm{NRE}_{\mathrm{ac}}$ from NPK in the wheat-maize rotation 
per year (in S2-CP, S3-ZZ and S4-YL) and the average of $\mathrm{NRE}_{\mathrm{ac}}$ was $75 \%$ with a standard deviation of $6 \%$ (Figure 1).

Table 2. Table 2. Average of $\mathrm{NRE}_{\mathrm{ac}}$ during 15 years at all sites.

\begin{tabular}{ccccccc}
\hline \multirow{2}{*}{ Treatment Experiment Site (\%) } \\
\cline { 2 - 7 } & S1-WQ1 & S1-WQ2 & S2-CP & S3-ZZ & S4-YL & S5-QY \\
\hline N & $149^{\mathrm{ab}}$ & $40^{\mathrm{b}}$ & $39^{\mathrm{e}}$ & $43^{\mathrm{f}}$ & $40^{\mathrm{c}}$ & $24^{\mathrm{e}}$ \\
NK & $115^{\mathrm{bc}}$ & $38^{\mathrm{bc}}$ & $47^{\mathrm{d}}$ & $50^{\mathrm{e}}$ & $42^{\mathrm{c}}$ & $30^{\mathrm{d}}$ \\
NP & $155^{\mathrm{ab}}$ & $58^{\mathrm{a}}$ & $66^{\mathrm{b}}$ & $77^{\mathrm{a}}$ & $70^{\mathrm{b}}$ & $39^{\mathrm{c}}$ \\
NPK & $161^{\mathrm{a}}$ & $62^{\mathrm{a}}$ & $70^{\mathrm{a}}$ & $78^{\mathrm{a}}$ & $77^{\mathrm{a}}$ & $43^{\mathrm{b}}$ \\
FS & $103^{\mathrm{c}}$ & $51^{\mathrm{ab}}$ & $48^{\mathrm{d}}$ & $64^{\mathrm{c}}$ & $74^{\mathrm{ab}}$ & $47^{\mathrm{ab}}$ \\
FM & $50^{\mathrm{d}}$ & $43^{\mathrm{b}}$ & $65^{\mathrm{b}}$ & $70^{\mathrm{b}}$ & $78^{\mathrm{a}}$ & $49^{\mathrm{a}}$ \\
HF & $31^{\mathrm{d}}$ & $26^{\mathrm{c}}$ & $58^{\mathrm{c}}$ & $56^{\mathrm{d}}$ & $71^{\mathrm{b}}$ & $47^{\mathrm{ab}}$ \\
\hline
\end{tabular}

Note: different letters indicate significance at 0.05 levels in a column; S1-WQ1 was an experiment at S1-WQ from 1990 to 1994 and S1-WQ2 from 1995 to 2004.

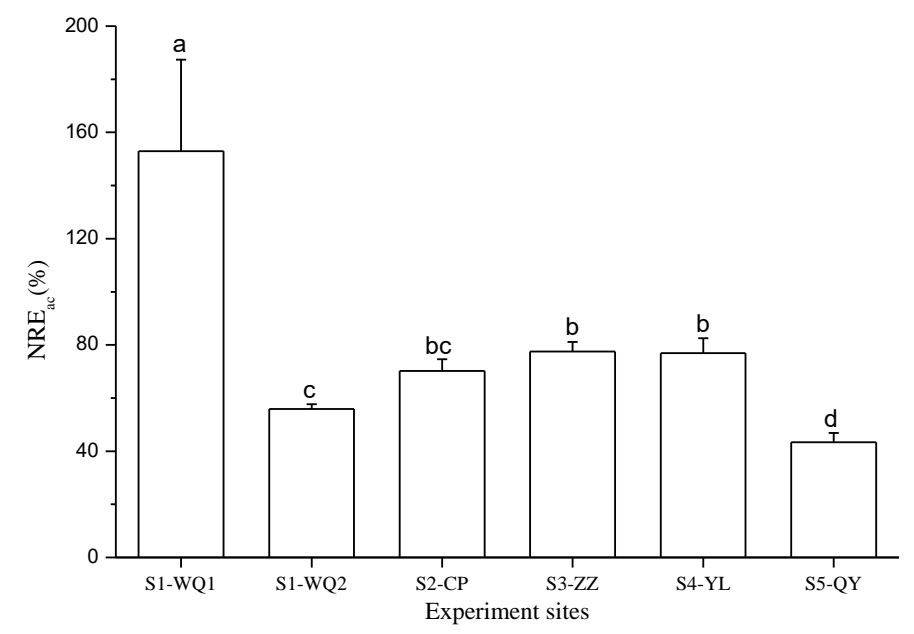

Figure 1. $\mathrm{NRE}_{\mathrm{ac}}$ from NPK in all sites. Note: Different letters indicate significant differences at 0.05 levels; $\mathrm{NRE}_{\mathrm{ac}}$ is apparent accumulated $\mathrm{N}$ recovery efficiency; S1-WQ1 is an experiment at Urumqi during 1991-1994; S1-WQ2 is an experiment at Urumqi during 1995-2005.

On the other hand, $\mathrm{NRE}_{\mathrm{ac}}$ was also affected by $\mathrm{N}$ rates. The higher $\mathrm{N}$ rates (HF) are always lower than normal $\mathrm{N}$ rates in $\mathrm{NRE}_{\mathrm{ac}}$ in all sites except S5-QY. Due to its location in the subtropical humid climate zone characterized by higher temperature (mean annual temperature $18.3^{\circ} \mathrm{C}$ ) and intensive precipitation (the sum of precipitation from Mar. to Aug. accounting for $70 \%$ of precipitation in a whole year), values of $\mathrm{NRE}_{\mathrm{ac}}$ from inorganic $\mathrm{N}$ treatments (N, NK, NP and NPK) are the lower than the combined treatments of inorganic and organic $\mathrm{N}$ in S5-QY. These results were mainly attributed to decreasing soil $\mathrm{pH}$. At the start of experiment, the initial soil $\mathrm{pH}$ in S5-QY was 5.7, where the growth of wheat and maize might be restricted. Furthermore, $\mathrm{N}$ fertilization accelerated soil acidification. In 2005, soil $\mathrm{pH}$ decreased approximately to 4 .

\subsection{Assessment of $N_{\text {fopt }}$ and Relationship between Yield $_{\text {opt }}$ and Yield 0}

Using 3414 data, correlations between $\mathrm{N}_{\mathrm{f} \text {.opt }}$ estimated by $\mathrm{NRE}_{\mathrm{ac}}$ and $\mathrm{N}_{\mathrm{f} \cdot \mathrm{opt}}$ measured with a quadratic curve are illustrated in Figure 2. For both of wheat and maize, the values of $r^{2}$ are above 0.9 with significant relationships $\left(p<0.01\right.$ ) which suggested that $\mathrm{NRE}_{\mathrm{ac}}$ of $75 \%$ from NPK in $\mathrm{S} 2-\mathrm{CP}$, S3-ZZ and S4-YL is an optimal NRE $\mathrm{Ac}_{\mathrm{ac}}$. Meanwhile, relationships between Yield $\mathrm{opt}_{\text {t }}$ and Yield $\mathrm{I}_{0}$ were illustrated in Figure 3, where values of $r^{2}$ are 0.62 and 0.73 for wheat and maize, respectively. And both correlations are significant $(p<0.01)$. 


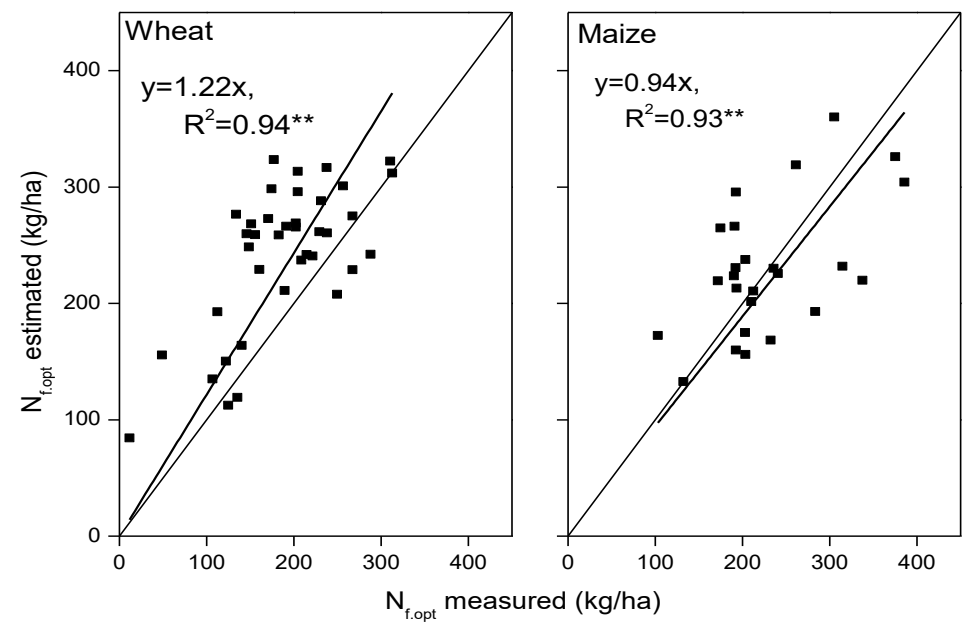

Figure 2. Correlation between $\mathrm{N}_{\text {f.opt }}$ estimated using $\mathrm{NRE}_{\mathrm{ac}}(75 \%)$ and $\mathrm{N}_{\text {f.opt }}$ measured using 3414 experiments with a quadratic curve fitting for wheat and maize. Note: ${ }^{* *}$ indicates significance at 0.01 level; $\mathrm{N}_{\text {f.opt }}$ is an economically optimal $\mathrm{N}$ rate; $\mathrm{NRE}_{\mathrm{ac}}$ is an apparent accumulated $\mathrm{N}$ recovery efficiency.

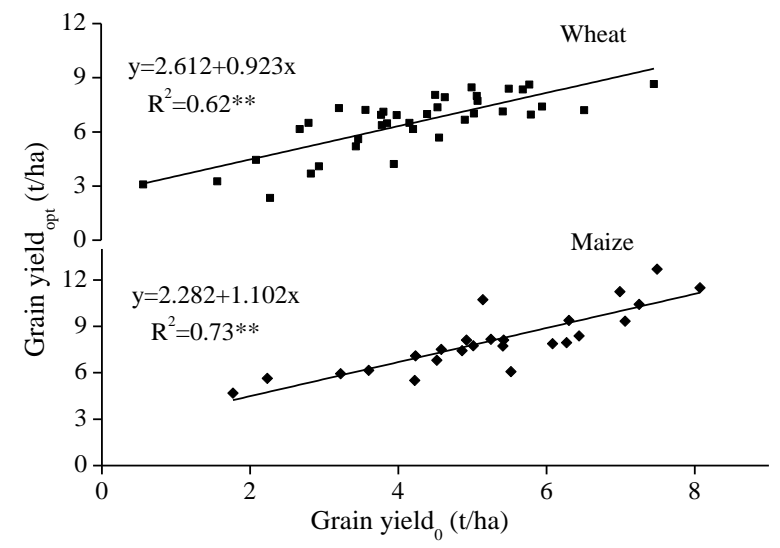

Figure 3. Relationships between grain yield opt $_{\text {and }}$ yield $\mathrm{d}_{0}$ for wheat and maize based on 3414 experiments. Note: ${ }^{* *}$ indicates significance at 0.01 levels; grain yield $\mathrm{opt}_{\mathrm{ot}}$ is a grain yield at $\mathrm{N}_{\text {f.opt }}$; grain yield $\mathrm{d}_{0}$ is a grain yield without $\mathrm{N}$ input.

\section{Discussion}

$\mathrm{NRE}_{\mathrm{ac}}$ are affected by cropping, soil properties and the environment, etc. Usually, crop rotation has higher nutrients recovery efficiency than monoculture. Long-term studies showed that crop rotation contributed to maintaining higher production levels [31]. Furthermore, the present study proved that the frequency of crop rotation could strengthen the trend outlined by Peterson and Varvel [32-34]. Without nutrient deficiency (from NPK, FS, FM and HF), NRE $\mathrm{ac}_{\mathrm{ac}}$ in a three-year rotation (S1-WQ2) was always far lower than from a one-year rotation except in S5-QY (Table 2 and Figure 1). Moreover, soil texture might have an effect on mineralization and immobilization of soil nitrogen that finally influenced $\mathrm{NRE}_{\mathrm{ac}}$. In the present study, clay content in S1-WQ and S5-QY were higher than in the other three sites (Table 1). Consequently, all $\mathrm{NRE}_{\mathrm{ac}}$ from sufficient nutrients were lower in S1-WQ2 and S5-QY than that in the other sites (Table 2 and Figure 1). This result was consisted with Hassink [35], who found that there was a significant negative relationship between clay content and the $\mathrm{N}$ mineralization rate. Soil $\mathrm{pH}$ is another soil property that affected $\mathrm{NRE}_{\mathrm{ac}}$. There was an initial lower soil $\mathrm{pH}$ of 5.7 (Table 1) and gradual acidification due to continuous $\mathrm{N}$ fertilization in S5-QY. Liu et al. [25] discussed the determinant for plant growth due to decreasing $\mathrm{pH}$, and eventually a lower $\mathrm{NRE}_{\mathrm{ac}}$ irreversibly occurred. In general, providing enough nutrients without other soil limitations in 
the same cropping period (S2-CP, S3-ZZ and S4-YL), NER ac from NPK had a narrow variation with a range of 6 and maintained a higher level (average of 75\%) (Table 2 and Figure 1).

The response of grain yield to applied N from NPK treatments is classically illustrated in Olfs et al. [8]. Grain yield increased with gradually increasing rate of applied N, which followed by an inflection point called an economically optimal yield (Yield ${ }_{\text {opt }}$ ) when the profit from an increased yield of added $\mathrm{N}$ equalled zero. The corresponding applied $\mathrm{N}$ rate is called the economically optimal $\mathrm{N}$ rate $\left(\mathrm{N}_{\mathrm{f} \text {.opt }}\right)$. Especially in the present study, grain yields were not significantly different between NPK and high N fertilization (HF) [25]. Therefore, based on the responses of grain yield to applied $\mathrm{N}$ [8], it was inferred that grain yield from NPK could be the Yield $\mathrm{opt}_{\text {and }}$ and corresponding $\mathrm{N}$ rate was equal to $\mathrm{N}_{\text {f.opt }}$. Furthermore, there is a good correlation of $\mathrm{N}_{\text {f.opt }}$ between estimated by $\mathrm{NRE}_{\mathrm{ac}}(75 \%)$ and measured using a quadratic curve-fitting with data from the '3414' design (Figure 2), which reconfirmed that the inference is correct. Therefore, the present study concluded that $\mathrm{NRE}_{\mathrm{ac}}$ of $75 \%$ could be equivalent to $\mathrm{NRE}_{\mathrm{ac} \cdot \text { opt }}$ and Equation (3) could be used to estimate $\mathrm{N}_{\text {f.opt }}$ in wheat-maize cropping systems in China.

When the $\mathrm{N}$ rate exceeds crop $\mathrm{N}$ requirement, there is an accumulation of $\mathrm{NO}_{3}{ }^{-}-\mathrm{N}$ in the soil profile $[36,37]$ as shown in Olfs et al. [8]. Moreover, the accumulated trend could be strengthened gradually with a further increasing $\mathrm{N}$ rate $[8,38]$. Previous research found that the content of $\mathrm{NO}_{3}{ }^{-}-\mathrm{N}$ from the NPK treatment used in the present study were lower in the $0-90 \mathrm{~cm}$ soil profile (approximate 100,30 and $60 \mathrm{~kg} \mathrm{ha}^{-1}$ in S2-CP, S3-ZZ and S4-YL, respectively) [39-41] which did not exceed the critical value of soil nitrate-N (a range of $66-118 \mathrm{~kg} \mathrm{ha}^{-1}$ ) in the top $90 \mathrm{~cm}$ of the soil profile for high yield in the wheat-maize cropping system [22,42]. Moreover, nitrate accumulation did not occur in the deeper soil profile [39-41]. All of these observations suggested that $\mathrm{N}$ rates from the NKP treatment would be the rational $\mathrm{N}$ rates again and further confirmed that the $\mathrm{N}$ rates could maintain the apparent $\mathrm{N}$ balance of a soil-plant system in the three sites.

However, accumulation of $\mathrm{NO}_{3}{ }^{-}-\mathrm{N}$ in soil profile and nitrate leaching into ground water were serious and prevalent in wheat-maize cropping system in China [43]. Initially, agronomist have focused on $\mathrm{NO}_{3}{ }^{-}-\mathrm{N}$ accumulation mostly for environment pollution [44] and gradually utilized them by the subsequent crop [22,42,45]. Cui et al. [42] reported that $\mathrm{NO}_{3}{ }^{-}-\mathrm{N}$ content in the top $90 \mathrm{~cm}$ soil should be maintained at a level of about $87 \mathrm{~kg} \mathrm{ha}^{-1}$ after maize harvest. Furthermore, the numerical relationship between residual soil- $\mathrm{N}$ and applied $\mathrm{N}$ was that $1 \mathrm{~kg}$ soil $\mathrm{NO}_{3}{ }^{-}-\mathrm{N}$ in the $0-90 \mathrm{~cm}$ soil profile was equivalent to $1.23 \mathrm{~kg}$ fertilizer- $\mathrm{N}$ [42]. The right side in Equation (3), therefore, should add $\mathrm{N}_{\mathrm{s}}$ to utilize the abundant $\mathrm{NO}_{3}{ }^{-}-\mathrm{N}$ using the following equation:

$$
\mathrm{N}_{\mathrm{s}}=-1.23 \times\left[\left(\mathrm{NO}_{3}{ }^{-}-\mathrm{N}\right)-87\right]
$$

where $\mathrm{NO}_{3}{ }^{-}-\mathrm{N}$ means the nitrate-N content $\left(\mathrm{kg} \mathrm{ha}^{-1}\right)$ in the top $90 \mathrm{~cm}$ soil profile, where $87 \mathrm{~kg} \mathrm{ha}^{-1}$ is a critical value of soil $\mathrm{NO}_{3}{ }^{-}-\mathrm{N}$ balancing the benefits between the economy and the environment. In other words, neither the nitrate leaching risk nor depletion of $\mathrm{NO}_{3}{ }^{-}-\mathrm{N}$ happens in a soil profile while the content of soil $\mathrm{NO}_{3}{ }^{-}-\mathrm{N}$ is maintained at the critical value.

The nitrate-N approach, however, would already provide a method to utilize the abundant soil residual $\mathrm{N}$, but implementation of the method is a challenge. One of the reasons is that the interval between the growth of maize and wheat is too short to determine soil nitrate in the wheat-maize cropping system in China. Additionally, the extension of the soil test at the farm level would be insurmountable due to the number of small farms involved. Therefore, a more feasible way for using $N_{s}$ was needed in the present study. Fortunately, Cui [22,42] reported that the relationship between grain yield of wheat and maize and initial soil $\mathrm{NO}_{3}{ }^{-}-\mathrm{N}$ content in the top $90 \mathrm{~cm}$ of the soil profile before sowing were fitted by the following equations:

$$
\begin{aligned}
& \mathrm{RY}_{\text {wheat }}(\%)=0.16 \times \mathrm{NO}_{3}{ }^{-}-\mathrm{N}+67.8 \\
& \mathrm{RY}_{\text {maize }}(\%)=0.21 \times \mathrm{NO}_{3}{ }^{-}-\mathrm{N}+60.4
\end{aligned}
$$


where $R Y_{\text {Wheat }}$ and $R Y_{\text {Maize }}$ are the relative yields to the local highest yields of wheat and maize, respectively. And 0.16 and 0.21 were numerical relationships between relative grain yield and initial $\mathrm{NO}_{3}{ }^{-}-\mathrm{N}(0-90 \mathrm{~cm}$ soil profile) for wheat and maize, respectively.

To maintain yields at a rational level, the content of soil $\mathrm{NO}_{3}{ }^{-}-\mathrm{N}$ has to keep up with the critical value. Combining of Equations (8)-(10) and Figure 3, $\mathrm{N}_{\mathrm{s}}$ could be calculated, called a basic soil productivity approach, using the following equations:

$$
\begin{aligned}
& \mathrm{N}_{\mathrm{s}}=-1.23 \times\left(\frac{\left.\left(\text { (ield }_{\text {opt }}-2615\right) /\left(0.923 \times \text { Yield }_{\text {opt }}\right)\right) \times 100-81.7}{0.16}\right) \\
& \mathrm{N}_{\mathrm{s}}=-1.23 \times\left(\frac{\left(\left(\text { Yield }_{\text {opt }}-2282\right) /\left(1.102 \times \text { Yield }_{\text {opt }}\right)\right) \times 100-78.7}{0.21}\right)
\end{aligned}
$$

where $81.7(\%)$ and $78.7(\%)$ are two critical values of $R Y_{\text {wheat }}$ and $R Y_{\text {maize, }}$ respectively. Exceeding the values means that $\mathrm{N}$ rate should be reduced in order to crop unitizing $\mathrm{N}$ from the abundant soil $\mathrm{NO}_{3}{ }^{-}-\mathrm{N}$. Yield $\mathrm{opt}_{\text {is }}$ is goal yield that was estimated by an average of recently five-year yields multiplied by 1.1 [46]. Therefore, the abundant soil $\mathrm{NO}_{3}{ }^{-}-\mathrm{N}$ could be utilized by a basic soil productivity approach more easily than a nitrate- $\mathrm{N}$ approach.

In general, yield-based $\mathrm{N}$ fertilizer recommendations were not completely accepted by agronomists and farmers at its inception due to limitations such as yield variability [47,48], uncertainty of $\mathrm{N}$ recovery efficiency estimated by the difference or isotopic methods [18] because of the complexity of the soil-supplying $\mathrm{N}$ capacity [19-21]. However, based on the present study, the theory of yield-based $\mathrm{N}$ fertilizer recommendation was further improved. Particularly, it could be adapted in the wheat-maize cropping areas in China.

\section{Conclusions}

Apparent accumulated nitrogen recovery $\left(\mathrm{NRE}_{\mathrm{ac}}\right)$ was affected by a multitude of factors. The present result that the three-year rotation (S1-WQ2) was always far lower than from the one-year rotation in $\mathrm{NRE}_{\mathrm{ac}}$ suggested that a frequent of crop rotation affected the $\mathrm{N}$ cycle. Moreover, soil texture also affected $\mathrm{NRE}_{\mathrm{ac}}$. In S1-WQ and S5-QY with higher soil clay contents, NRE $\mathrm{Ec}_{\mathrm{ac}}$ from all treatments were always lower than that in the other sites with lower soil clay contents. In general, from the NPK treatment in S2-CP, S3-ZZ and S4-YL, the nitrate contents were lower and its accumulation did not occur in the soil profile. In other words, the present study provided evidence that $\mathrm{N}$ applied from the NPK treatment maintained an apparent $\mathrm{N}$ balance in the soil-plant system in the three sites. Meanwhile, NER $\mathrm{ac}$ had a narrow variation with a range of $6 \%$ and maintained a higher level (average of $75 \%$ ). Furthermore, grain yield from NPK in the three sites were the Yield ${ }_{\text {opt }}$ where $\mathrm{NRE}_{\mathrm{ac}}$ could be equal to that at $\mathrm{N}_{\text {f.opt }}$. Additionally, based on the fact of accumulation of $\mathrm{NO}_{3}{ }^{-}-\mathrm{N}$ in the soil profile being serious and prevalent in the wheat-maize cropping system in China, $\mathrm{NO}_{3}{ }^{-}-\mathrm{N}$ should be utilized by subsequent crops. However, due to the logistical obstacle of determining profile $\mathrm{NO}_{3}{ }^{-}-\mathrm{N}$ at the farm level, a basic soil productivity approach was advocated in the present study. A yield-based $\mathrm{N}$ fertilizer recommendation was proposed in the present study yet needs to be further evaluated. For example, the critical value of $\mathrm{NO}_{3}{ }^{-}-\mathrm{N}$ is variable and should be adjusted in relation to soil type and management.

Author Contributions: Formal analysis, Y.J. and Q.L.; Funding acquisition, J.L. (Jie Liu) and Q.L.; Investigation, J.L. (Jie Liu); Resources, J.L. (Jumei Li) and Y.M.; Supervision, Y.M.; Writing—original draft, J.L. (Jie Liu).

Funding: This research was funded by National key R \& D program (2016YFD0200301) and Scientific Research Project of Beijing Educational Committee (KM201710020008).

Acknowledgments: The authors thank all scientists associated with the National Long-Term Monitoring Network of Soil Fertility and Fertilizer Effects in China for providing the historic dataset of the long-term experiments, and Phillip M. Chalk for review and correction for English.

Conflicts of Interest: The authors declare no conflict of interest. 


\section{Appendix A}

Table A1. 3414 data quoted from CSTJ (China Science and Technology Journal Database).

\begin{tabular}{|c|c|c|c|c|c|c|c|}
\hline \multirow{2}{*}{$\frac{\text { Sites }}{\text { Village, Province }}$} & \multirow[t]{2}{*}{ Treatments } & \multicolumn{3}{|c|}{ Applied Rate $\left(\mathrm{kg} \mathrm{ha}^{-1}\right)$} & \multirow{2}{*}{$\begin{array}{c}\text { Grain Yield }\left(\mathrm{kg} \mathrm{ha}^{-1}\right) \\
\text { Wheat }\end{array}$} & \multirow[t]{2}{*}{$r^{2}$} & \multirow[t]{2}{*}{ References } \\
\hline & & $\mathrm{N}$ & $\mathrm{P}$ & K & & & \\
\hline Kaoshan, & $\mathrm{N}_{0} \mathrm{P}_{2} \mathrm{~K}_{2}$ & 0 & 72 & 150 & 4260 & 0.946 & 1 \\
\hline \multirow[t]{3}{*}{ Anhui } & $\mathrm{N}_{1} \mathrm{P}_{2} \mathrm{~K}_{2}$ & 90 & 72 & 150 & 5280 & & \\
\hline & $\mathrm{N}_{2} \mathrm{P}_{2} \mathrm{~K}_{2}$ & 180 & 72 & 150 & 6645 & & \\
\hline & $\mathrm{N}_{3} \mathrm{P}_{2} \mathrm{~K}_{2}$ & 270 & 72 & 150 & 6390 & & \\
\hline Xinji, & $\mathrm{N}_{0} \mathrm{P}_{2} \mathrm{~K}_{2}$ & 0 & 26 & 75 & 2766 & 0.997 & 2 \\
\hline \multirow[t]{3}{*}{ Anhui } & $\mathrm{N}_{1} \mathrm{P}_{2} \mathrm{~K}_{2}$ & 98 & 26 & 75 & 4820 & & \\
\hline & $\mathrm{N}_{2} \mathrm{P}_{2} \mathrm{~K}_{2}$ & 195 & 26 & 75 & 5852 & & \\
\hline & $\mathrm{N}_{3} \mathrm{P}_{2} \mathrm{~K}_{2}$ & 293 & 26 & 75 & 6524 & & \\
\hline \multirow{4}{*}{$\begin{array}{l}\text { Gupeizhen, } \\
\text { Anhui }\end{array}$} & $\mathrm{N}_{0} \mathrm{P}_{2} \mathrm{~K}_{2}$ & 0 & 90 & 150 & 3178 & 0.997 & 3 \\
\hline & $\mathrm{N}_{1} \mathrm{P}_{2} \mathrm{~K}_{2}$ & 90 & 90 & 150 & 6392 & & \\
\hline & $\mathrm{N}_{2} \mathrm{P}_{2} \mathrm{~K}_{2}$ & 180 & 90 & 150 & 7206 & & \\
\hline & $\mathrm{N}_{3} \mathrm{P}_{2} \mathrm{~K}_{2}$ & 270 & 90 & 150 & 6321 & & \\
\hline \multirow{4}{*}{$\begin{array}{l}\text { Hengshan, } \\
\text { Anhui }\end{array}$} & $\mathrm{N}_{0} \mathrm{P}_{2} \mathrm{~K}_{2}$ & 0 & 90 & 150 & 4435 & 0.993 & 3 \\
\hline & $\mathrm{N}_{1} \mathrm{P}_{2} \mathrm{~K}_{2}$ & 90 & 90 & 150 & 5728 & & \\
\hline & $\mathrm{N}_{2} \mathrm{P}_{2} \mathrm{~K}_{2}$ & 180 & 90 & 150 & 6826 & & \\
\hline & $\mathrm{N}_{3} \mathrm{P}_{2} \mathrm{~K}_{2}$ & 270 & 90 & 150 & 6964 & & \\
\hline \multirow{4}{*}{$\begin{array}{l}\text { Mingdong, } \\
\text { Anhui }\end{array}$} & $\mathrm{N}_{0} \mathrm{P}_{2} \mathrm{~K}_{2}$ & 0 & 90 & 150 & 5195 & 0.940 & 3 \\
\hline & $\mathrm{N}_{1} \mathrm{P}_{2} \mathrm{~K}_{2}$ & 90 & 90 & 150 & 6818 & & \\
\hline & $\mathrm{N}_{2} \mathrm{P}_{2} \mathrm{~K}_{2}$ & 180 & 90 & 150 & 8358 & & \\
\hline & $\mathrm{N}_{3} \mathrm{P}_{2} \mathrm{~K}_{2}$ & 270 & 90 & 150 & 7318 & & \\
\hline \multirow{4}{*}{$\begin{array}{l}\text { Nongkesuo, } \\
\text { Anhui }\end{array}$} & $\mathrm{N}_{0} \mathrm{P}_{2} \mathrm{~K}_{2}$ & 0 & 90 & 150 & 4040 & 0.990 & 3 \\
\hline & $\mathrm{N}_{1} \mathrm{P}_{2} \mathrm{~K}_{2}$ & 90 & 90 & 150 & 5912 & & \\
\hline & $\mathrm{N}_{2} \mathrm{P}_{2} \mathrm{~K}_{2}$ & 180 & 90 & 150 & 7070 & & \\
\hline & $\mathrm{N}_{3} \mathrm{P}_{2} \mathrm{~K}_{2}$ & 270 & 90 & 150 & 6502 & & \\
\hline \multirow{4}{*}{$\begin{array}{l}\text { Pancun, } \\
\text { Anhui }\end{array}$} & $\mathrm{N}_{0} \mathrm{P}_{2} \mathrm{~K}_{2}$ & 0 & 90 & 150 & 5460 & 0.994 & 3 \\
\hline & $\mathrm{N}_{1} \mathrm{P}_{2} \mathrm{~K}_{2}$ & 90 & 90 & 150 & 7463 & & \\
\hline & $\mathrm{N}_{2} \mathrm{P}_{2} \mathrm{~K}_{2}$ & 180 & 90 & 150 & 8160 & & \\
\hline & $\mathrm{N}_{3} \mathrm{P}_{2} \mathrm{~K}_{2}$ & 270 & 90 & 150 & 8314 & & \\
\hline & $\mathrm{N}_{0} \mathrm{P}_{2} \mathrm{~K}_{2}$ & 0 & 90 & 150 & 3847 & 0.984 & 3 \\
\hline Anhui & $\mathrm{N}_{1} \mathrm{P}_{2} \mathrm{~K}_{2}$ & 90 & 90 & 150 & 6084 & & \\
\hline & $\mathrm{N}_{2} \mathrm{P}_{2} \mathrm{~K}_{2}$ & 180 & 90 & 150 & 7121 & & \\
\hline & $\mathrm{N}_{3} \mathrm{P}_{2} \mathrm{~K}_{2}$ & 270 & 90 & 150 & 5630 & & \\
\hline Shiba, & $\mathrm{N}_{0} \mathrm{P}_{2} \mathrm{~K}_{2}$ & 0 & 90 & 150 & 3551 & 0.999 & 3 \\
\hline Anhui & $\mathrm{N}_{1} \mathrm{P}_{2} \mathrm{~K}_{2}$ & 90 & 90 & 150 & 6027 & & \\
\hline & $\mathrm{N}_{2} \mathrm{P}_{2} \mathrm{~K}_{2}$ & 180 & 90 & 150 & 7050 & & \\
\hline & $\mathrm{N}_{3} \mathrm{P}_{2} \mathrm{~K}_{2}$ & 270 & 90 & 150 & 7022 & & \\
\hline Zhaoxin, & $\mathrm{N}_{0} \mathrm{P}_{2} \mathrm{~K}_{2}$ & 0 & 90 & 150 & 5220 & 0.920 & 3 \\
\hline Anhui & $\mathrm{N}_{1} \mathrm{P}_{2} \mathrm{~K}_{2}$ & 90 & 90 & 150 & 6183 & & \\
\hline & $\mathrm{N}_{2} \mathrm{P}_{2} \mathrm{~K}_{2}$ & 180 & 90 & 150 & 7878 & & \\
\hline & $\mathrm{N}_{3} \mathrm{P}_{2} \mathrm{~K}_{2}$ & 270 & 90 & 150 & 7586 & & \\
\hline Longkang, & $\mathrm{N}_{0} \mathrm{P}_{2} \mathrm{~K}_{2}$ & 0 & 52 & 124 & 2754 & 0.984 & 4 \\
\hline Anhui & $\mathrm{N}_{1} \mathrm{P}_{2} \mathrm{~K}_{2}$ & 98 & 52 & 124 & 4367 & & \\
\hline & $\mathrm{N}_{2} \mathrm{P}_{2} \mathrm{~K}_{2}$ & 195 & 52 & 124 & 5987 & & \\
\hline & $\mathrm{N}_{3} \mathrm{P}_{2} \mathrm{~K}_{2}$ & 293 & 52 & 124 & 6090 & & \\
\hline Xiaolou, & $\mathrm{N}_{0} \mathrm{P}_{2} \mathrm{~K}_{2}$ & 0 & 43 & 81 & 5147 & 0.908 & 5 \\
\hline Anhui & $\mathrm{N}_{1} \mathrm{P}_{2} \mathrm{~K}_{2}$ & 98 & 43 & 81 & 5876 & & \\
\hline & $\mathrm{N}_{2} \mathrm{P}_{2} \mathrm{~K}_{2}$ & 195 & 43 & 81 & 7209 & & \\
\hline & $\mathrm{N}_{3} \mathrm{P}_{2} \mathrm{~K}_{2}$ & 293 & 43 & 81 & 6917 & & \\
\hline Gaohuang, & $\mathrm{N}_{0} \mathrm{P}_{2} \mathrm{~K}_{2}$ & 0 & 33 & 81 & 4545 & 1.000 & 6 \\
\hline Anhui & $\mathrm{N}_{1} \mathrm{P}_{2} \mathrm{~K}_{2}$ & 113 & 33 & 81 & 6240 & & \\
\hline & $\mathrm{N}_{2} \mathrm{P}_{2} \mathrm{~K}_{2}$ & 225 & 33 & 81 & 7200 & & \\
\hline & $\mathrm{N}_{3} \mathrm{P}_{2} \mathrm{~K}_{2}$ & 338 & 33 & 81 & 7350 & & \\
\hline Xuji, & $\mathrm{N}_{0} \mathrm{P}_{2} \mathrm{~K}_{2}$ & 0 & 26 & 75 & 4223 & 0.999 & 7 \\
\hline Anhui & $\mathrm{N}_{1} \mathrm{P}_{2} \mathrm{~K}_{2}$ & 90 & 26 & 75 & 5646 & & \\
\hline & $\mathrm{N}_{2} \mathrm{P}_{2} \mathrm{~K}_{2}$ & 180 & 26 & 75 & 6198 & & \\
\hline & $\mathrm{N}_{3} \mathrm{P}_{2} \mathrm{~K}_{2}$ & 270 & 26 & 75 & 5663 & & \\
\hline Toupu, & $\mathrm{N}_{0} \mathrm{P}_{2} \mathrm{~K}_{2}$ & 0 & 39 & 62 & 3945 & 0.952 & 8 \\
\hline Anhui & $\mathrm{N}_{1} \mathrm{P}_{2} \mathrm{~K}_{2}$ & 83 & 39 & 62 & 5444 & & \\
\hline & $\mathrm{N}_{2} \mathrm{P}_{2} \mathrm{~K}_{2}$ & 165 & 39 & 62 & 7314 & & \\
\hline & $\mathrm{N}_{3} \mathrm{P}_{2} \mathrm{~K}_{2}$ & 248 & 39 & 62 & 6935 & & \\
\hline Yonggu, & $\mathrm{N}_{0} \mathrm{P}_{2} \mathrm{~K}_{2}$ & 0 & 39 & 60 & 5475 & 0.972 & 9 \\
\hline Anhui & $\mathrm{N}_{1} \mathrm{P}_{2} \mathrm{~K}_{2}$ & 90 & 39 & 60 & 6375 & & \\
\hline
\end{tabular}


Table A1. Cont.

\begin{tabular}{|c|c|c|c|c|c|c|c|}
\hline \multirow[t]{2}{*}{ Sites } & \multirow{2}{*}{$\begin{array}{c}\text { Treatments } \\
\mathrm{N}_{2} \mathrm{P}_{2} \mathrm{~K}_{2}\end{array}$} & \multicolumn{3}{|c|}{ Applied Rate (kg ha $\left.{ }^{-1}\right)$} & \multirow{2}{*}{$\frac{\text { Grain Yield }\left(\mathrm{kg} \mathrm{ha}^{-\mathbf{1}}\right)}{7238}$} & \multirow[t]{2}{*}{$r^{2}$} & \multirow[t]{2}{*}{ References } \\
\hline & & 180 & 39 & 60 & & & \\
\hline & $\mathrm{N}_{3} \mathrm{P}_{2} \mathrm{~K}_{2}$ & 270 & 39 & 60 & 7035 & & \\
\hline \multirow{4}{*}{$\begin{array}{l}\text { Dazhuang (a), } \\
\text { Gansu }\end{array}$} & $\mathrm{N}_{0} \mathrm{P}_{2} \mathrm{~K}_{2}$ & 0 & 39 & 87 & 3522 & 0.921 & 10 \\
\hline & $\mathrm{N}_{1} \mathrm{P}_{2} \mathrm{~K}_{2}$ & 60 & 39 & 87 & 4482 & & \\
\hline & $\mathrm{N}_{2} \mathrm{P}_{2} \mathrm{~K}_{2}$ & 120 & 39 & 87 & 5460 & & \\
\hline & $\mathrm{N}_{3} \mathrm{P}_{2} \mathrm{~K}_{2}$ & 180 & 39 & 87 & 4716 & & \\
\hline \multirow{4}{*}{$\begin{array}{l}\text { Dazhuang (b), } \\
\text { Gansu }\end{array}$} & $\mathrm{N}_{0} \mathrm{P}_{2} \mathrm{~K}_{2}$ & 0 & 39 & 87 & 1511 & 0.963 & 10 \\
\hline & $\mathrm{N}_{1} \mathrm{P}_{2} \mathrm{~K}_{2}$ & 60 & 39 & 87 & 2825 & & \\
\hline & $\mathrm{N}_{2} \mathrm{P}_{2} \mathrm{~K}_{2}$ & 120 & 39 & 87 & 3021 & & \\
\hline & $\mathrm{N}_{3} \mathrm{P}_{2} \mathrm{~K}_{2}$ & 180 & 39 & 87 & 3263 & & \\
\hline \multirow{4}{*}{$\begin{array}{l}\text { Handian, } \\
\text { Gansu }\end{array}$} & $\mathrm{N}_{0} \mathrm{P}_{2} \mathrm{~K}_{2}$ & 0 & 39 & 87 & 2883 & 0.898 & 10 \\
\hline & $\mathrm{N}_{1} \mathrm{P}_{2} \mathrm{~K}_{2}$ & 60 & 39 & 87 & 3294 & & \\
\hline & $\mathrm{N}_{2} \mathrm{P}_{2} \mathrm{~K}_{2}$ & 120 & 39 & 87 & 3833 & & \\
\hline & $\mathrm{N}_{3} \mathrm{P}_{2} \mathrm{~K}_{2}$ & 180 & 39 & 87 & 3512 & & \\
\hline \multirow{4}{*}{$\begin{array}{l}\text { Nanhu, } \\
\text { Gansu }\end{array}$} & $\mathrm{N}_{0} \mathrm{P}_{2} \mathrm{~K}_{2}$ & 0 & 39 & 87 & 3960 & 0.995 & 10 \\
\hline & $\mathrm{N}_{1} \mathrm{P}_{2} \mathrm{~K}_{2}$ & 60 & 39 & 87 & 4200 & & \\
\hline & $\mathrm{N}_{2} \mathrm{P}_{2} \mathrm{~K}_{2}$ & 120 & 39 & 87 & 4095 & & \\
\hline & $\mathrm{N}_{3} \mathrm{P}_{2} \mathrm{~K}_{2}$ & 180 & 39 & 87 & 3465 & & \\
\hline \multirow{4}{*}{$\begin{array}{l}\text { Tonghua, } \\
\text { Gansu }\end{array}$} & $\mathrm{N}_{0} \mathrm{P}_{2} \mathrm{~K}_{2}$ & 0 & 39 & 87 & 2129 & 0.990 & 10 \\
\hline & $\mathrm{N}_{1} \mathrm{P}_{2} \mathrm{~K}_{2}$ & 60 & 39 & 87 & 3458 & & \\
\hline & $\mathrm{N}_{2} \mathrm{P}_{2} \mathrm{~K}_{2}$ & 120 & 39 & 87 & 4467 & & \\
\hline & $\mathrm{N}_{3} \mathrm{P}_{2} \mathrm{~K}_{2}$ & 180 & 39 & 87 & 4322 & & \\
\hline & $\mathrm{N}_{0} \mathrm{P}_{2} \mathrm{~K}_{2}$ & 0 & 39 & 87 & 3020 & 0.855 & 10 \\
\hline Gansu & $\mathrm{N}_{1} \mathrm{P}_{2} \mathrm{~K}_{2}$ & 60 & 39 & 87 & 3455 & & \\
\hline & $\mathrm{N}_{2} \mathrm{P}_{2} \mathrm{~K}_{2}$ & 120 & 39 & 87 & 4313 & & \\
\hline & $\mathrm{N}_{3} \mathrm{P}_{2} \mathrm{~K}_{2}$ & 180 & 39 & 87 & 3932 & & \\
\hline Yuebao, & $\mathrm{N}_{0} \mathrm{P}_{2} \mathrm{~K}_{2}$ & 0 & 39 & 87 & 2297 & 0.708 & 10 \\
\hline Gansu & $\mathrm{N}_{1} \mathrm{P}_{2} \mathrm{~K}_{2}$ & 60 & 39 & 87 & 2314 & & \\
\hline & $\mathrm{N}_{2} \mathrm{P}_{2} \mathrm{~K}_{2}$ & 120 & 39 & 87 & 2409 & & \\
\hline & $\mathrm{N}_{3} \mathrm{P}_{2} \mathrm{~K}_{2}$ & 180 & 39 & 87 & 2168 & & \\
\hline Zhaodun, & $\mathrm{N}_{0} \mathrm{P}_{2} \mathrm{~K}_{2}$ & 0 & 39 & 87 & 834 & 0.728 & 10 \\
\hline Gansu & $\mathrm{N}_{1} \mathrm{P}_{2} \mathrm{~K}_{2}$ & 60 & 39 & 87 & 1536 & & \\
\hline & $\mathrm{N}_{2} \mathrm{P}_{2} \mathrm{~K}_{2}$ & 120 & 39 & 87 & 3858 & & \\
\hline & $\mathrm{N}_{3} \mathrm{P}_{2} \mathrm{~K}_{2}$ & 180 & 39 & 87 & 2505 & & \\
\hline Gaocheng (City, a), & $\mathrm{N}_{0} \mathrm{P}_{2} \mathrm{~K}_{2}$ & 0 & 65 & 124 & 5805 & 0.998 & 11 \\
\hline Hebei & $\mathrm{N}_{1} \mathrm{P}_{2} \mathrm{~K}_{2}$ & 113 & 65 & 124 & 6795 & & \\
\hline & $\mathrm{N}_{2} \mathrm{P}_{2} \mathrm{~K}_{2}$ & 225 & 65 & 124 & 6915 & & \\
\hline & $\mathrm{N}_{3} \mathrm{P}_{2} \mathrm{~K}_{2}$ & 338 & 65 & 124 & 5985 & & \\
\hline Gaocheng (City, b), & $\mathrm{N}_{0} \mathrm{P}_{2} \mathrm{~K}_{2}$ & 0 & 65 & 124 & 5685 & 0.967 & 11 \\
\hline Hebei & $\mathrm{N}_{1} \mathrm{P}_{2} \mathrm{~K}_{2}$ & 113 & 65 & 124 & 7545 & & \\
\hline & $\mathrm{N}_{2} \mathrm{P}_{2} \mathrm{~K}_{2}$ & 225 & 65 & 124 & 7950 & & \\
\hline & $\mathrm{N}_{3} \mathrm{P}_{2} \mathrm{~K}_{2}$ & 338 & 65 & 124 & 8715 & & \\
\hline Gaocheng (City, c), & $\mathrm{N}_{0} \mathrm{P}_{2} \mathrm{~K}_{2}$ & 0 & 65 & 124 & 6555 & 0.925 & 11 \\
\hline Hebei & $\mathrm{N}_{1} \mathrm{P}_{2} \mathrm{~K}_{2}$ & 113 & 65 & 124 & 6915 & & \\
\hline & $\mathrm{N}_{2} \mathrm{P}_{2} \mathrm{~K}_{2}$ & 225 & 65 & 124 & 7350 & & \\
\hline & $\mathrm{N}_{3} \mathrm{P}_{2} \mathrm{~K}_{2}$ & 338 & 65 & 124 & 7140 & & \\
\hline Gaocheng (City, d), & $\mathrm{N}_{0} \mathrm{P}_{2} \mathrm{~K}_{2}$ & 0 & 65 & 100 & 5910 & 0.980 & 11 \\
\hline Hebei & $\mathrm{N}_{1} \mathrm{P}_{2} \mathrm{~K}_{2}$ & 90 & 65 & 100 & 7275 & & \\
\hline & $\mathrm{N}_{2} \mathrm{P}_{2} \mathrm{~K}_{2}$ & 180 & 65 & 100 & 7260 & & \\
\hline & $\mathrm{N}_{3} \mathrm{P}_{2} \mathrm{~K}_{2}$ & 270 & 65 & 100 & 6570 & & \\
\hline Wangguaying, & $\mathrm{N}_{0} \mathrm{P}_{2} \mathrm{~K}_{2}$ & 0 & 31 & 60 & 4886 & 0.995 & 12 \\
\hline Henan & $\mathrm{N}_{1} \mathrm{P}_{2} \mathrm{~K}_{2}$ & 81 & 31 & 60 & 6270 & & \\
\hline & $\mathrm{N}_{2} \mathrm{P}_{2} \mathrm{~K}_{2}$ & 162 & 31 & 60 & 6615 & & \\
\hline & $\mathrm{N}_{3} \mathrm{P}_{2} \mathrm{~K}_{2}$ & 243 & 31 & 60 & 6324 & & \\
\hline Xieqiaozhen, & $\mathrm{N}_{0} \mathrm{P}_{2} \mathrm{~K}_{2}$ & 0 & 39 & 87 & 3810 & 0.989 & 13 \\
\hline Jiangsu & $\mathrm{N}_{1} \mathrm{P}_{2} \mathrm{~K}_{2}$ & 105 & 39 & 87 & 5745 & & \\
\hline & $\mathrm{N}_{2} \mathrm{P}_{2} \mathrm{~K}_{2}$ & 210 & 39 & 87 & 6270 & & \\
\hline & $\mathrm{N}_{3} \mathrm{P}_{2} \mathrm{~K}_{2}$ & 315 & 39 & 87 & 6345 & & \\
\hline Liutao, & $\mathrm{N}_{0} \mathrm{P}_{2} \mathrm{~K}_{2}$ & 0 & 33 & 50 & 4503 & 0.930 & 14 \\
\hline Jiangsu & $\mathrm{N}_{1} \mathrm{P}_{2} \mathrm{~K}_{2}$ & 135 & 33 & 50 & 5623 & & \\
\hline & $\mathrm{N}_{2} \mathrm{P}_{2} \mathrm{~K}_{2}$ & 270 & 33 & 50 & 5558 & & \\
\hline & $\mathrm{N}_{3} \mathrm{P}_{2} \mathrm{~K}_{2}$ & 405 & 33 & 50 & 5367 & & \\
\hline Sitaocun, & $\mathrm{N}_{0} \mathrm{P}_{2} \mathrm{~K}_{2}$ & 0 & 33 & 50 & 3420 & 0.979 & 15 \\
\hline Jiangsu & $\mathrm{N}_{1} \mathrm{P}_{2} \mathrm{~K}_{2}$ & 135 & 33 & 50 & 5145 & & \\
\hline & $\mathrm{N}_{2} \mathrm{P}_{2} \mathrm{~K}_{2}$ & 270 & 33 & 50 & 5445 & & \\
\hline & $\mathrm{N}_{3} \mathrm{P}_{2} \mathrm{~K}_{2}$ & 405 & 33 & 50 & 5400 & & \\
\hline Qianshan, & $\mathrm{N}_{0} \mathrm{P}_{2} \mathrm{~K}_{2}$ & 0 & 37 & 31 & 4770 & 0.946 & 16 \\
\hline
\end{tabular}


Table A1. Cont.

\begin{tabular}{|c|c|c|c|c|c|c|c|}
\hline \multirow{2}{*}{$\begin{array}{c}\text { Sites } \\
\text { Qinghai }\end{array}$} & \multirow{2}{*}{$\begin{array}{c}\text { Treatments } \\
\mathrm{N}_{1} \mathrm{P}_{2} \mathrm{~K}_{2}\end{array}$} & \multicolumn{3}{|c|}{ Applied Rate (kg ha $\left.{ }^{-1}\right)$} & \multirow{2}{*}{$\begin{array}{c}\left.\text { Grain Yield (kg ha }{ }^{-1}\right) \\
5760\end{array}$} & \multirow[t]{2}{*}{$r^{2}$} & \multirow[t]{2}{*}{ References } \\
\hline & & 59 & 37 & 31 & & & \\
\hline & $\mathrm{N}_{2} \mathrm{P}_{2} \mathrm{~K}_{2}$ & 117 & 37 & 31 & 7571 & & \\
\hline \multirow{5}{*}{$\begin{array}{l}\text { Chengguan, } \\
\text { Shaanxi }\end{array}$} & $\mathrm{N}_{3} \mathrm{P}_{2} \mathrm{~K}_{2}$ & 176 & 37 & 31 & 7650 & & \\
\hline & $\mathrm{N}_{0} \mathrm{P}_{2} \mathrm{~K}_{2}$ & 0 & 120 & 90 & 7464 & 1.000 & 17 \\
\hline & $\mathrm{N}_{1} \mathrm{P}_{2} \mathrm{~K}_{2}$ & 75 & 120 & 90 & 8122 & & \\
\hline & $\mathrm{N}_{2} \mathrm{P}_{2} \mathrm{~K}_{2}$ & 150 & 120 & 90 & 8543 & & \\
\hline & $\mathrm{N}_{3} \mathrm{P}_{2} \mathrm{~K}_{2}$ & 225 & 120 & 90 & 8671 & & \\
\hline \multirow{4}{*}{$\begin{array}{l}\text { Chuanyuan, } \\
\text { Shaanxi }\end{array}$} & $\mathrm{N}_{0} \mathrm{P}_{2} \mathrm{~K}_{2}$ & 0 & 52 & 100 & 4458 & 0.993 & 18 \\
\hline & $\mathrm{N}_{1} \mathrm{P}_{2} \mathrm{~K}_{2}$ & 90 & 52 & 100 & 6568 & & \\
\hline & $\mathrm{N}_{2} \mathrm{P}_{2} \mathrm{~K}_{2}$ & 180 & 52 & 100 & 7442 & & \\
\hline & $\mathrm{N}_{3} \mathrm{P}_{2} \mathrm{~K}_{2}$ & 270 & 52 & 100 & 8111 & & \\
\hline Qili, & $\mathrm{N}_{0} \mathrm{P}_{2} \mathrm{~K}_{2}$ & 0 & 28 & 60 & 3750 & 0.992 & 19 \\
\hline \multirow[t]{3}{*}{ Sichuan } & $\mathrm{N}_{1} \mathrm{P}_{2} \mathrm{~K}_{2}$ & 59 & 28 & 60 & 5040 & & \\
\hline & $\mathrm{N}_{2} \mathrm{P}_{2} \mathrm{~K}_{2}$ & 117 & 28 & 60 & 5622 & & \\
\hline & $\mathrm{N}_{3} \mathrm{P}_{2} \mathrm{~K}_{2}$ & 176 & 28 & 60 & 6260 & & \\
\hline Qixiang, & $\mathrm{N}_{0} \mathrm{P}_{2} \mathrm{~K}_{2}$ & 0 & 90 & 30 & 5760 & 0.973 & 20 \\
\hline \multirow[t]{3}{*}{ Xinjiang } & $\mathrm{N}_{1} \mathrm{P}_{2} \mathrm{~K}_{2}$ & 98 & 90 & 30 & 6690 & & \\
\hline & $\mathrm{N}_{2} \mathrm{P}_{2} \mathrm{~K}_{2}$ & 195 & 90 & 30 & 7980 & & \\
\hline & $\mathrm{N}_{3} \mathrm{P}_{2} \mathrm{~K}_{2}$ & 293 & 90 & 30 & 8175 & & \\
\hline Zepu (County), & $\mathrm{N}_{0} \mathrm{P}_{2} \mathrm{~K}_{2}$ & 0 & 39 & 25 & 5000 & 1.000 & 21 \\
\hline \multirow[t]{4}{*}{ Xinjiang } & $\mathrm{N}_{1} \mathrm{P}_{2} \mathrm{~K}_{2}$ & 93 & 39 & 25 & 7046 & & \\
\hline & $\mathrm{N}_{2} \mathrm{P}_{2} \mathrm{~K}_{2}$ & 186 & 39 & 25 & 8182 & & \\
\hline & $\mathrm{N}_{3} \mathrm{P}_{2} \mathrm{~K}_{2}$ & 279 & 39 & 25 & 8455 & & \\
\hline & & & & & Maize & & \\
\hline Caozhuang, & $\mathrm{N}_{0} \mathrm{P}_{2} \mathrm{~K}_{2}$ & 0 & 589 & 75 & 5562 & 0.895 & 22 \\
\hline Anhui & $\mathrm{N}_{1} \mathrm{P}_{2} \mathrm{~K}_{2}$ & 113 & 589 & 75 & 5926 & & \\
\hline & $\mathrm{N}_{2} \mathrm{P}_{2} \mathrm{~K}_{2}$ & 225 & 589 & 75 & 6176 & & \\
\hline & $\mathrm{N}_{3} \mathrm{P}_{2} \mathrm{~K}_{2}$ & 338 & 589 & 75 & 5548 & & \\
\hline Sanshipu, & $\mathrm{N}_{0} \mathrm{P}_{2} \mathrm{~K}_{2}$ & 0 & 47 & 119 & 5259 & 0.999 & 23 \\
\hline Anhui & $\mathrm{N}_{1} \mathrm{P}_{2} \mathrm{~K}_{2}$ & 150 & 47 & 119 & 7069 & & \\
\hline & $\mathrm{N}_{2} \mathrm{P}_{2} \mathrm{~K}_{2}$ & 300 & 47 & 119 & 8112 & & \\
\hline & $\mathrm{N}_{3} \mathrm{P}_{2} \mathrm{~K}_{2}$ & 450 & 47 & 119 & 8108 & & \\
\hline Gengzhuang, & $\mathrm{N}_{0} \mathrm{P}_{2} \mathrm{~K}_{2}$ & 0 & 52 & 100 & 10869 & 0.967 & 24 \\
\hline Liaoning & $\mathrm{N}_{1} \mathrm{P}_{2} \mathrm{~K}_{2}$ & 105 & 52 & 100 & 12300 & & \\
\hline & $\mathrm{N}_{2} \mathrm{P}_{2} \mathrm{~K}_{2}$ & 210 & 52 & 100 & 12401 & & \\
\hline & $\mathrm{N}_{3} \mathrm{P}_{2} \mathrm{~K}_{2}$ & 315 & 52 & 100 & 12134 & & \\
\hline Sandu(a), & $\mathrm{N}_{0} \mathrm{P}_{2} \mathrm{~K}_{2}$ & 0 & 26 & 124 & 6204 & 0.967 & 25 \\
\hline Guangxi & $\mathrm{N}_{1} \mathrm{P}_{2} \mathrm{~K}_{2}$ & 105 & 26 & 124 & 8898 & & \\
\hline & $\mathrm{N}_{2} \mathrm{P}_{2} \mathrm{~K}_{2}$ & 210 & 26 & 124 & 9102 & & \\
\hline & $\mathrm{N}_{3} \mathrm{P}_{2} \mathrm{~K}_{2}$ & 315 & 26 & 124 & 8726 & & \\
\hline Caohai, & $\mathrm{N}_{0} \mathrm{P}_{2} \mathrm{~K}_{2}$ & 0 & 380 & 274 & 8266 & 0.988 & 26 \\
\hline Guizhou & $\mathrm{N}_{1} \mathrm{P}_{2} \mathrm{~K}_{2}$ & 235 & 380 & 274 & 9942 & & \\
\hline & $\mathrm{N}_{2} \mathrm{P}_{2} \mathrm{~K}_{2}$ & 470 & 380 & 274 & 9845 & & \\
\hline & $\mathrm{N}_{3} \mathrm{P}_{2} \mathrm{~K}_{2}$ & 705 & 380 & 274 & 10614 & & \\
\hline Shazi(a), & $\mathrm{N}_{0} \mathrm{P}_{2} \mathrm{~K}_{2}$ & 0 & 52 & 149 & 5369 & 0.967 & 27 \\
\hline Guizhou & $\mathrm{N}_{1} \mathrm{P}_{2} \mathrm{~K}_{2}$ & 90 & 52 & 149 & 7204 & & \\
\hline & $\mathrm{N}_{2} \mathrm{P}_{2} \mathrm{~K}_{2}$ & 180 & 52 & 149 & 7604 & & \\
\hline & $\mathrm{N}_{3} \mathrm{P}_{2} \mathrm{~K}_{2}$ & 270 & 52 & 149 & 7437 & & \\
\hline Shazi(b), & $\mathrm{N}_{0} \mathrm{P}_{2} \mathrm{~K}_{2}$ & 0 & 65 & 199 & 6503 & 0.998 & 27 \\
\hline Guizhou & $\mathrm{N}_{1} \mathrm{P}_{2} \mathrm{~K}_{2}$ & 113 & 65 & 199 & 7637 & & \\
\hline & $\mathrm{N}_{2} \mathrm{P}_{2} \mathrm{~K}_{2}$ & 225 & 65 & 199 & 8571 & & \\
\hline & $\mathrm{N}_{3} \mathrm{P}_{2} \mathrm{~K}_{2}$ & 338 & 65 & 199 & 8071 & & \\
\hline Tianping, & $\mathrm{N}_{0} \mathrm{P}_{2} \mathrm{~K}_{2}$ & 0 & 59 & 174 & 8199 & 1.000 & 28 \\
\hline Guizhou & $\mathrm{N}_{1} \mathrm{P}_{2} \mathrm{~K}_{2}$ & 105 & 59 & 174 & 8653 & & \\
\hline & $\mathrm{N}_{2} \mathrm{P}_{2} \mathrm{~K}_{2}$ & 210 & 59 & 174 & 8639 & & \\
\hline & $\mathrm{N}_{3} \mathrm{P}_{2} \mathrm{~K}_{2}$ & 315 & 59 & 174 & 9204 & & \\
\hline Lejian(a), & $\mathrm{N}_{0} \mathrm{P}_{2} \mathrm{~K}_{2}$ & 0 & 52 & 149 & 1766 & 0.987 & 29 \\
\hline Guizhou & $\mathrm{N}_{1} \mathrm{P}_{2} \mathrm{~K}_{2}$ & 90 & 52 & 149 & 4295 & & \\
\hline & $\mathrm{N}_{2} \mathrm{P}_{2} \mathrm{~K}_{2}$ & 180 & 52 & 149 & 4467 & & \\
\hline & $\mathrm{N}_{3} \mathrm{P}_{2} \mathrm{~K}_{2}$ & 270 & 52 & 149 & 2298 & & \\
\hline Lejian(b), & $\mathrm{N}_{0} \mathrm{P}_{2} \mathrm{~K}_{2}$ & 0 & 59 & 174 & 4176 & 0.996 & 29 \\
\hline Guizhou & $\mathrm{N}_{1} \mathrm{P}_{2} \mathrm{~K}_{2}$ & 105 & 59 & 174 & 6392 & & \\
\hline & $\mathrm{N}_{2} \mathrm{P}_{2} \mathrm{~K}_{2}$ & 210 & 59 & 174 & 6902 & & \\
\hline & $\mathrm{N}_{3} \mathrm{P}_{2} \mathrm{~K}_{2}$ & 315 & 59 & 174 & 6854 & & \\
\hline Zhuping (County, a), & $\mathrm{N}_{0} \mathrm{P}_{2} \mathrm{~K}_{2}$ & 0 & 39 & 75 & 4886 & 1.000 & 30 \\
\hline Henan & $\mathrm{N}_{1} \mathrm{P}_{2} \mathrm{~K}_{2}$ & 120 & 39 & 75 & 6683 & & \\
\hline & $\mathrm{N}_{2} \mathrm{P}_{2} \mathrm{~K}_{2}$ & 240 & 39 & 75 & 7518 & & \\
\hline
\end{tabular}


Table A1. Cont.

\begin{tabular}{|c|c|c|c|c|c|c|c|}
\hline \multirow[t]{2}{*}{ Sites } & \multirow{2}{*}{$\begin{array}{c}\text { Treatments } \\
\mathrm{N}_{3} \mathrm{P}_{2} \mathrm{~K}_{2}\end{array}$} & \multicolumn{3}{|c|}{ Applied Rate (kg ha $\left.{ }^{-1}\right)$} & \multirow{2}{*}{$\begin{array}{c}\text { Grain Yield }\left(\mathrm{kg} \mathrm{ha}^{-\mathbf{1}}\right) \\
6828\end{array}$} & \multirow[t]{2}{*}{$r^{2}$} & \multirow[t]{2}{*}{ References } \\
\hline & & 360 & 39 & 75 & & & \\
\hline \multirow{4}{*}{$\begin{array}{l}\text { Zhuping (County, b), } \\
\text { Henan }\end{array}$} & $\mathrm{N}_{0} \mathrm{P}_{2} \mathrm{~K}_{2}$ & 0 & 39 & 75 & 5423 & 0.995 & 30 \\
\hline & $\mathrm{N}_{1} \mathrm{P}_{2} \mathrm{~K}_{2}$ & 120 & 39 & 75 & 7265 & & \\
\hline & $\mathrm{N}_{2} \mathrm{P}_{2} \mathrm{~K}_{2}$ & 240 & 39 & 75 & 8100 & & \\
\hline & $\mathrm{N}_{3} \mathrm{P}_{2} \mathrm{~K}_{2}$ & 360 & 39 & 75 & 7857 & & \\
\hline \multirow{4}{*}{$\begin{array}{l}\text { Zhuping (County, c), } \\
\text { Henan }\end{array}$} & $\mathrm{N}_{0} \mathrm{P}_{2} \mathrm{~K}_{2}$ & 0 & 33 & 62 & 4962 & 0.999 & 30 \\
\hline & $\mathrm{N}_{1} \mathrm{P}_{2} \mathrm{~K}_{2}$ & 105 & 33 & 62 & 7203 & & \\
\hline & $\mathrm{N}_{2} \mathrm{P}_{2} \mathrm{~K}_{2}$ & 210 & 33 & 62 & 8255 & & \\
\hline & $\mathrm{N}_{3} \mathrm{P}_{2} \mathrm{~K}_{2}$ & 315 & 33 & 62 & 7322 & & \\
\hline \multirow{4}{*}{$\begin{array}{c}\text { Zhuping (County, d), } \\
\text { Henan }\end{array}$} & $\mathrm{N}_{0} \mathrm{P}_{2} \mathrm{~K}_{2}$ & 0 & 33 & 62 & 4590 & 0.964 & 30 \\
\hline & $\mathrm{N}_{1} \mathrm{P}_{2} \mathrm{~K}_{2}$ & 105 & 33 & 62 & 6713 & & \\
\hline & $\mathrm{N}_{2} \mathrm{P}_{2} \mathrm{~K}_{2}$ & 210 & 33 & 62 & 7560 & & \\
\hline & $\mathrm{N}_{3} \mathrm{P}_{2} \mathrm{~K}_{2}$ & 315 & 33 & 62 & 6870 & & \\
\hline \multirow{4}{*}{$\begin{array}{c}\text { Zhuping (County, e), } \\
\text { Henan }\end{array}$} & $\mathrm{N}_{0} \mathrm{P}_{2} \mathrm{~K}_{2}$ & 0 & 33 & 62 & 3311 & 0.997 & 30 \\
\hline & $\mathrm{N}_{1} \mathrm{P}_{2} \mathrm{~K}_{2}$ & 105 & 33 & 62 & 4658 & & \\
\hline & $\mathrm{N}_{2} \mathrm{P}_{2} \mathrm{~K}_{2}$ & 210 & 33 & 62 & 6102 & & \\
\hline & $\mathrm{N}_{3} \mathrm{P}_{2} \mathrm{~K}_{2}$ & 315 & 33 & 62 & 5778 & & \\
\hline \multirow{4}{*}{$\begin{array}{l}\text { Zhuping (County, f), } \\
\text { Henan }\end{array}$} & $\mathrm{N}_{0} \mathrm{P}_{2} \mathrm{~K}_{2}$ & 0 & 26 & 50 & 4806 & 0.998 & 30 \\
\hline & $\mathrm{N}_{1} \mathrm{P}_{2} \mathrm{~K}_{2}$ & 90 & 26 & 50 & 5429 & & \\
\hline & $\mathrm{N}_{2} \mathrm{P}_{2} \mathrm{~K}_{2}$ & 180 & 26 & 50 & 6228 & & \\
\hline & $\mathrm{N}_{3} \mathrm{P}_{2} \mathrm{~K}_{2}$ & 270 & 26 & 50 & & & \\
\hline \multirow{4}{*}{$\begin{array}{c}\text { Jiaohe (City), } \\
\text { Jilin }\end{array}$} & $\mathrm{N}_{0} \mathrm{P}_{2} \mathrm{~K}_{2}$ & 0 & 26 & 62 & 7275 & 0.993 & 31 \\
\hline & $\mathrm{N}_{1} \mathrm{P}_{2} \mathrm{~K}_{2}$ & 75 & 26 & 62 & 9030 & & \\
\hline & $\mathrm{N}_{2} \mathrm{P}_{2} \mathrm{~K}_{2}$ & 150 & 26 & 62 & 10230 & & \\
\hline & $\mathrm{N}_{3} \mathrm{P}_{2} \mathrm{~K}_{2}$ & 225 & 26 & 62 & 10395 & & \\
\hline Shuangdian, & $\mathrm{N}_{0} \mathrm{P}_{2} \mathrm{~K}_{2}$ & 0 & 21 & 102 & 5054 & 0.941 & 32 \\
\hline Jiangsu & $\mathrm{N}_{1} \mathrm{P}_{2} \mathrm{~K}_{2}$ & 150 & 21 & 102 & 8607 & & \\
\hline & $\mathrm{N}_{2} \mathrm{P}_{2} \mathrm{~K}_{2}$ & 300 & 21 & 102 & 9970 & & \\
\hline & $\mathrm{N}_{3} \mathrm{P}_{2} \mathrm{~K}_{2}$ & 450 & 21 & 102 & 10813 & & \\
\hline Wangji, & $\mathrm{N}_{0} \mathrm{P}_{2} \mathrm{~K}_{2}$ & 0 & 39 & 100 & 5130 & 0.998 & 33 \\
\hline Jiangsu & $\mathrm{N}_{1} \mathrm{P}_{2} \mathrm{~K}_{2}$ & 165 & 39 & 100 & 6375 & & \\
\hline & $\mathrm{N}_{2} \mathrm{P}_{2} \mathrm{~K}_{2}$ & 330 & 39 & 100 & 8025 & & \\
\hline & $\mathrm{N}_{3} \mathrm{P}_{2} \mathrm{~K}_{2}$ & 495 & 39 & 100 & 7620 & & \\
\hline Gengzhuang (b), & $\mathrm{N}_{0} \mathrm{P}_{2} \mathrm{~K}_{2}$ & 0 & 52 & 100 & 6245 & 0.986 & 34 \\
\hline Liaoning & $\mathrm{N}_{1} \mathrm{P}_{2} \mathrm{~K}_{2}$ & 90 & 52 & 100 & 7620 & & \\
\hline & $\mathrm{N}_{2} \mathrm{P}_{2} \mathrm{~K}_{2}$ & 180 & 52 & 100 & 8349 & & \\
\hline & $\mathrm{N}_{3} \mathrm{P}_{2} \mathrm{~K}_{2}$ & 270 & 52 & 100 & 8100 & & \\
\hline Yezhai, & $\mathrm{N}_{0} \mathrm{P}_{2} \mathrm{~K}_{2}$ & 0 & 65 & 50 & 6905 & 0.999 & 35 \\
\hline Ningxia & $\mathrm{N}_{1} \mathrm{P}_{2} \mathrm{~K}_{2}$ & 113 & 65 & 50 & 9944 & & \\
\hline & $\mathrm{N}_{2} \mathrm{P}_{2} \mathrm{~K}_{2}$ & 225 & 65 & 50 & 10779 & & \\
\hline & $\mathrm{N}_{3} \mathrm{P}_{2} \mathrm{~K}_{2}$ & 338 & 65 & 50 & 11219 & & \\
\hline Huangguan, & $\mathrm{N}_{0} \mathrm{P}_{2} \mathrm{~K}_{2}$ & 0 & 52 & 50 & 4268 & 0.994 & 36 \\
\hline Ningxia & $\mathrm{N}_{1} \mathrm{P}_{2} \mathrm{~K}_{2}$ & 248 & 52 & 50 & 7016 & & \\
\hline & $\mathrm{N}_{2} \mathrm{P}_{2} \mathrm{~K}_{2}$ & 495 & 52 & 50 & 8577 & & \\
\hline & $\mathrm{N}_{3} \mathrm{P}_{2} \mathrm{~K}_{2}$ & 743 & 52 & 50 & 8129 & & \\
\hline Gongu (County), & $\mathrm{N}_{0} \mathrm{P}_{2} \mathrm{~K}_{2}$ & 0 & 72 & 49 & 12330 & 0.994 & 1 \\
\hline Xinjiang & $\mathrm{N}_{1} \mathrm{P}_{2} \mathrm{~K}_{2}$ & 48 & 72 & 49 & 13140 & & \\
\hline & $\mathrm{N}_{2} \mathrm{P}_{2} \mathrm{~K}_{2}$ & 97 & 72 & 49 & 13350 & & \\
\hline & $\mathrm{N}_{3} \mathrm{P}_{2} \mathrm{~K}_{2}$ & 145 & 72 & 49 & 14820 & & \\
\hline Wenyaer, & $\mathrm{N}_{0} \mathrm{P}_{2} \mathrm{~K}_{2}$ & 0 & 42 & 25 & 11700 & 0.994 & 38 \\
\hline Xinjiang & $\mathrm{N}_{1} \mathrm{P}_{2} \mathrm{~K}_{2}$ & 113 & 42 & 25 & 14588 & & \\
\hline & $\mathrm{N}_{2} \mathrm{P}_{2} \mathrm{~K}_{2}$ & 225 & 42 & 25 & 16538 & & \\
\hline & $\mathrm{N}_{3} \mathrm{P}_{2} \mathrm{~K}_{2}$ & 338 & 42 & 25 & 12278 & & \\
\hline Jiucheng, & $\mathrm{N}_{0} \mathrm{P}_{2} \mathrm{~K}_{2}$ & 0 & 33 & 50 & 4553 & 0.970 & 39 \\
\hline Yunnan & $\mathrm{N}_{1} \mathrm{P}_{2} \mathrm{~K}_{2}$ & 113 & 33 & 50 & 5654 & & \\
\hline & $\mathrm{N}_{2} \mathrm{P}_{2} \mathrm{~K}_{2}$ & 225 & 33 & 50 & 6603 & & \\
\hline & $\mathrm{N}_{3} \mathrm{P}_{2} \mathrm{~K}_{2}$ & 338 & 33 & 50 & 6804 & & \\
\hline Luoxiong, & $\mathrm{N}_{0} \mathrm{P}_{2} \mathrm{~K}_{2}$ & 0 & 52 & 90 & 6326 & 0.960 & 40 \\
\hline Yunnan & $\mathrm{N}_{1} \mathrm{P}_{2} \mathrm{~K}_{2}$ & 138 & 52 & 90 & 7268 & & \\
\hline & $\mathrm{N}_{2} \mathrm{P}_{2} \mathrm{~K}_{2}$ & 276 & 52 & 90 & 8111 & & \\
\hline & $\mathrm{N}_{3} \mathrm{P}_{2} \mathrm{~K}_{2}$ & 414 & 52 & 90 & 7808 & & \\
\hline Zhongcun, & $\mathrm{N}_{0} \mathrm{P}_{2} \mathrm{~K}_{2}$ & 0 & 24 & 75 & 3510 & 0.986 & 41 \\
\hline Zhejiang & $\mathrm{N}_{1} \mathrm{P}_{2} \mathrm{~K}_{2}$ & 86 & 24 & 75 & 5444 & & \\
\hline & $\mathrm{N}_{2} \mathrm{P}_{2} \mathrm{~K}_{2}$ & 173 & 24 & 75 & 5734 & & \\
\hline & $\mathrm{N}_{3} \mathrm{P}_{2} \mathrm{~K}_{2}$ & 259 & 24 & 75 & 6240 & & \\
\hline
\end{tabular}




\section{Appendix References}

1. Huang, S.; Zhang, Z. Study on "3414" fertilizer effect experiment of wheat in kaoshan village, Dingyuan County in 2006. Agric. Technol. Serv. 2008, 25, 39-40. (In Chinese)

2. Li, J.; Li, Z.; Li, K.; Huang, S. Report on "3414" fertilization experiment of wheat. Anhui Agric. Sci. Bull. 2008, 14, 142-175. (In Chinese)

3. You, J.; Zhou, F.; Li, P.; Yu, Y.; Ma, B.; Jiang, H. Study on soil testing and fertilization of wheat in Mingguang City. Anhui Agric. Sci. Bull. 2007, 13, 120-122. (In Chinese)

4. Ma, L.; Zhao, Y.; Yang, L.; Zhan, Q.; Fang, Y. Preliminary report on "3414" fertilization experiment of wheat. Anhui Agric. Sci. Bull. 2009, 15, 90-189. (In Chinese)

5. Zhang, W. Report on fertilizer effect of "3414" field wheat experiment. Anhui Agric. Sci. Bull. 2009, 15, 62-63, 167. (In Chinese)

6. Dai, H. Report on "3414" formula fertilization experiment of wheat. Anhui Agric. Sci. Bull. 2009, 15, 131-132. (In Chinese)

7. Zhang, D.; Liu, L.; Hu, S.; Zhao, Q. Preliminary report on "3414" fertilizer effect experiment of wheat. J. Anhui Agric. Sci. 2008, 36, 15587-15589. (In Chinese)

8. Liu, S. Report on "3414" fertilizer effect field wheat experiment in Wuhe County in 2007. Anhui Agric. Sci. Bull. 2008, 14, 89, 105. (In Chinese)

9. Wu, X.; Chen, J.; Wang, G.; Xu, H. Study on the economic benefits of balance fertilizer of N, P and $\mathrm{K}$ to wheat. J. Hebei Agric. Sci. 2008, 12, 47-48, 78. (In Chinese)

10. Zhao, Z. Study on indices of soil testing and fertilization of wheat in Zhuanglang County. Gansu Agric. Sci. Technol. 2009, 7, 30-33. (In Chinese)

11. Sun, Y.; Du, J.; Jia, L.; Liu, M. Study on fertilizer effect of " 3414 " experiment of winter wheat in Gaocheng city, Hebei province. J. Hebei Agric. Sci. 2008, 12, 84-86. (In Chinese)

12. Li, M.; Wang, L. Preliminary report on "3414" experiment of winter wheat in Lushang County in 2007. Anhui Agric. Sci. Bull. 2008, 14, 67-71. (In Chinese)

13. Chen, A.; Jiang, D.; Wang, H.; Mao, X. A "3414" fertilizer effect experiment of weak gluten wheat in oil sandy soil. Mod. Agric. Sci. Technol. 2009, 19, 15-16. (In Chinese)

14. Gong, C. Preliminary study on fertilization of P and K to wheat. Barly Cereal Sci. 2008, 1, 39-42. (In Chinese)

15. Wang, K.; Zhu, H.; Wu, L.; Xu, 1. Fertilization effect of "3414" experiment on wheat in Sandy loam soil in Xiangshui County in 2007-2008. Mod. Agric. Sci. Technol. 2008, 24, 177-178. (In Chinese)

16. Ren, J. Fertilization effect of "3414" experiment on wheat in Guide County shallow hill region. Agric. Technol. Serv. 2009, 26, 40. (In Chinese)

17. Fan, L.; He, L. Preliminary report on "3414" fertilizer effect experiment of wheat. Plant Prot. 2009, 11, 35-36. (In Chinese)

18. Du, J.; Zhu, S.; Yuan, W.; Hou, X. The application of "3414" experiment in the production of Wheat. Shaanxi J. Agric. Sci. 2009, 6, 12-14. (In Chinese)

19. Li, C. Study on of "3414" fertilizer effect experiment of wheat. Jiangsu Agric. Sci. 2009, 4, 336-338. (In Chinese)

20. Li, W. Summary on "3414" experiment of wheat in Maigaiti County. Xinjiang Agric. Sci. Technol. 2008, 180, 27. (In Chinese)

21. Tuohetiniyazi, N.; Ta, Y. Summary on "3414" experiment of winter wheat. Xinjiang Agric. Sci. Technol. 2008, 181, 29. (In Chinese)

22. Shao, L. Fertilization effect of "3414" experiment on summer maize. Anhui Agric. Sci. Bull. 2008, 14, 129-130. (In Chinese)

23. Sun, Y. Fertilization effect of "3414" field experiment on maize in Yingzhou region in 2008. Mod. Agric. Sci. Technol. 2009, 15, 12, 14. (In Chinese) 
24. Huang, L. Study on "3414" fertilizer effect experiment of maize in Gengzhuang town, Haicheng city. Rain Fed Crops 2009, 29, 148-149. (In Chinese)

25. Wei, Z.; Zeng, G.; Wei, M.; Peng, C. Preliminary report on fertilizer effect of "3414" soil testing and fertilization experiment on maize. Mod. Agric. Sci. 2009, 16, 48-49, 51. (In Chinese)

26. Deng, D.; Xiao, G.; Wei, X.; Liu, Q.; Kong, F. Fertilizer effect on maize with "3414" experiment in high elevation mountainous area of Weining County. Mod. Agric. Sci. Technol. 2009, 5, 156, 158. (In Chinese)

27. Jiang, Z. “3414" fertilizer effect experiment of maize in Qinglong County. Agric. Technol. Serv. 2008, 25, 45-46. (In Chinese)

28. Yuan, M. "3414+1" fertilizer effect experiment of maize in Tianping country, Tongzhi County. Agric. Technol. Serv. 2009, 26, 38-39. (In Chinese)

29. Huang, L.; Kuang, Y.; Feng, S.; Zhen, L.; He, D. Fertilization effect of "3414" experiment on maize in yellow earths. Agric. Technol. Serv. 2009, 26, 50-51. (In Chinese)

30. Yan, H.; Jing, S.; Song, Q.; Zhang, J.; Song, X. Preliminary report on "3414" fertilizer effect field experiment of summer maize. J. Seed Ind. Guide 2009, 3, 27-29. (In Chinese)

31. Jin, F.; Yan, X.; Lin, Y.; Gao, Y.; Liu, W. Study on fertilizer effect of N, P and K on maize. J. Jilin Agric. Sci. 2008, 33, 48-50. (In Chinese)

32. Shen, J.; Song, Y.; Mao, B.; Xu, Q.L.C.; Zhou, M. Preliminary study on "3414" fertilizer effect experiment of maize in albic soils in Donghai County. Mod. Agric. 2009, 3, 29-30. (In Chinese)

33. Wang, L.; Wang, C.; Liu, Y. “3414” fertilizer effect experiment of maize. Mod. Agric. Sci. Technol. 2008, 15, 201-202.

34. Shao, L. "3414" fertilizer effect experiment of summer maize. Anhui Agric. Sci. Bull. 2008, 14, 129-130. (In Chinese)

35. Wang, W.; He, X.; Wang, G.; Wang, L.; Li, X.; Li, W. “3414” fertilizer effect experiment of maize in southern Ningxia mountain area. Ningxia J. Agric. For. Sci. Technol. 2008, 6, 77-79. (In Chinese)

36. Yin, X.; Zhu, G.; Ji, W.; Sun, W.; Wang, S.; Dong, P. Effects of "3414" different fertilizer ratio experiment on the yield of maize interplanted with wheat in Ningxia. Ningxia J. Agric. For. Sci. Technol. 2008, 3, 31-32. (In Chinese)

37. Shadekebieke, T.; Baxian, W. Study on "3414" fertilizer experiment of maize. Rural Sci. Technol. 2008, 2, 19-20. (In Chinese)

38. Wang, N.; Yang, A.; Huang, H.; Wu, S.; Wang, T. Report of "3414" experiment of maize in Wenyaer vellige, Yining County. Xinjiang Agric. Sci. Technol. 2008, 182, 25. (In Chinese)

39. Zhu, N.; Wan, Y.; He, Y.; Du, W. Preliminary report on "3414" soil testing and fertilization experiment of maize in Luxi County. Yunnan Agric. Sci. Technol. 2009, S, 51-52. (In Chinese)

40. Qin, X.; Ruan, Y. Study on "3414" soil testing and fertilization experiment of maize in Luoping County. Yunnan Agric. 2009, 4, 26-27. (In Chinese)

41. Chen, X. Preliminary report on optimal fertilization of maize in southern Zhejiang yellow mud gravel area. Mod. Agric. Sci. Technol. 2008, 24, 181, 184. (In Chinese)

\section{References}

1. Cassman, K.; Dobermann, A.; Walters, D. Agroecosystems, nitrogen-use efficiency, and nitrogen management. AMBIO J. Hum. Environ. 2002, 31, 132-140. [CrossRef]

2. Frink, C.; Waggoner, P.; Ausubel, J. Nitrogen fertilizer: Retrospect and prospect. Proc. Natl. Acad. Sci. USA 1999, 96, 1175-1180. [CrossRef] [PubMed]

3. Roy, R.; Misra, R.; Montanez, A. Decreasing reliance on mineral nitrogen-yet more food. AMBIO J. Hum. Environ. 2002, 31, 177-183. [CrossRef]

4. National Bureau of Statistics. China Statistical Yearbook; China Statistics Press: Beijing, China, 2012.

5. Fixen, P.; West, F. Nitrogen fertilizers: Meeting contemporary challenges. AMBIO J. Hum. Environ. 2002, 31, 169-176. [CrossRef] 
6. Tilman, D.; Cassman, K.; Matson, P.; Naylor, R.; Polasky, S. Agricultural sustainability and intensive production practices. Nature 2002, 418, 671-677. [CrossRef]

7. Liu, G.; Wu, W.; Zhang, J. Regional differentiation of non-point source pollution of agriculture-derived nitrate nitrogen in groundwater in northern China. Agric. Ecosyst. Environ. 2005, 107, 211-220. [CrossRef]

8. Olfs, H.; Blankenau, K.; Brentrup, F.; Jasper, J.; Link, A.; Lammel, J. Soil-and plant-based nitrogen-fertilizer recommendations in arable farming. J. Plant Nutr. Soil Sc. 2005, 168, 414-431. [CrossRef]

9. Hong, N.; Scharf, P.; Davis, J.; Kitchen, N.; Sudduth, K. Economically optimal nitrogen rate reduces soil residual nitrate. J. Environ. Qual. 2007, 36, 354-362. [CrossRef]

10. Benbi, D.; Biswas, C. Nitrogen balance and $\mathrm{N}$ recovery after 22 years of maize-wheat-cowpea cropping in a long-term experiment. Nutr. Cycl. Agroecosyst. 1996, 47, 107-114. [CrossRef]

11. Truog, E. Fifty years of soil testing. In Proceedings of the Transactions of 7 th International Congress of Soil Science, Madison, WI, USA, 15 August 1960; Volume 4, pp. 46-52.

12. Stanford, G. Rationale for optimum nitrogen fertilization in corn production. J. Environ. Qual. 1973, 2, 159-166. [CrossRef]

13. Stanford, G.; Hunter, A. Nitrogen requirements of winter wheat (Triticum aestivum, L.) varieties 'Blueboy'and 'Redcoat'. Agron. J. 1973, 65, 442-447. [CrossRef]

14. Shapiro, C.A.; Ferguson, R.B.; Hergert, G.W.; Wortmann, C.S.; Walters, D.T. Fertilizer Suggestions for Corn. 2003. Available online: http://www.ianrpubs.unl.edu/live/ec117/build/ec117.pdf (accessed on 3 October 2018).

15. Beegle, D.; Wolf, A. Soil Test Recommendations Handbook for Agronomic Crops; Agricultural Analytical Services Lab, Pennsylvania State University: University Park, TX, USA, USA. 2000; Available online: https:/ /agsci. psu.edu/aasl/soil-testing/soil-fertility-testing/handbooks/agronomic (accessed on 3 October 2018).

16. Hoeft, R.; Peck, T.; Boone, L. Soil testing and fertility. In Illinois Agronomy Handbook: 2000-2001; University of Illinois: Urbana-Champaign, IL, USA, 2001; pp. 84-124.

17. Dahnke, W.; Fanning, C.; Cattanach, A.; Fertilizing Corn Grain, Popcorn, Silage Corn, and Sweet Corn. North Dakota State University Institutional Repository. 2010. Available online: http://hdlhandlenet/10365/9362 (accessed on 3 October 2012).

18. Rao, A.; Smith, J.; Parr, J.; Papendick, R. Considerations in estimating nitrogen recovery efficiency by the difference and isotopic dilution methods. Fertil. Res. 1992, 33, 209-217. [CrossRef]

19. Stanford, G.; Legg, J. Correlation of soil N availability indexes with N uptake by plants. Soil Sci. 1968, 105, 320-326. [CrossRef]

20. Storrier, R.; Hanly, A.; Nicol, H. An evaluation of indices of available soil nitrogen. Anim. Prod. Sci. 1970, 10, 89-94. [CrossRef]

21. Schomberg, H.; Wietholter, S.; Griffin, T.; Reeves, D.; Cabrera, M.; Fisher, D.; Endale, D.; Novak, J.; Balkcom, K.; Raper, R. Assessing indices for predicting potential nitrogen mineralization in soils under different management systems. Soil Sci. Soc. Am. J. 2009, 73, 1575-1586. [CrossRef]

22. Cui, Z.; Chen, X.; Miao, Y.; Li, F.; Zhang, F.; Li, J.; Ye, Y.; Yang, Z.; Zhang, Q.; Liu, C. On-farm evaluation of winter wheat yield response to residual soil nitrate-N in North China Plain. Agron. J. 2008, 100, 1527-1534. [CrossRef]

23. Lund, L. Variations in nitrate and chloride concentrations below selected agricultural fields. Soil Sci. Soc. Am. J. 1982, 46, 1062-1066. [CrossRef]

24. Tanji, K.; Fried, M.; Van De Pol, R. A steady-state conceptual nitrogen model for estimating nitrogen emissions from cropped lands. J. Environ. Qual. 1977, 6, 155-159. [CrossRef]

25. Liu, J.; Liu, H.; Huang, S.; Yang, X.; Wang, B.; Li, X.; Ma, Y. Nitrogen efficiency in long-term wheat-maize cropping systems under diverse field sites in China. Field Crop Res. 2010, 118, 145-151. [CrossRef]

26. Page, A.L. Part 2. Chemical and microbiological properties. In Methods of Soil Analysis; Wi American Society of Agronomy Inc. \& Soil Science Society of America Inc.: Wisconsin, USA, 1982.

27. Meisinger, J. Evaluating plant-available nitrogen in soil-crop systems. Nitrogen Crop Prod. 1984, 4, $391-416$.

28. Gaffke, N.; Krafft, O. Exact D-optimum designs for quadratic regression. J. R. Stat. Soc. B 1982, 44, $394-397$.

29. Chen, X.; Zhang, F. Construction of index system on soil test and formula fertilization based on 3414 experiment. China Agric. Technol. Ext. 2006, 22, 36-39. (In Chinese)

30. NAPCIDC. National Agricultural Product Cost and Income Data Compilation; China Statistics Press: Beijing, China, 2015. (In Chinese) 
31. Mitchell, C.; Westerman, R.; Brown, J.; Peck, T. Overview of long-term agronomic research. Agron. J. 1991, 83, 24-29. [CrossRef]

32. Peterson, T.; Varvel, G. Crop yield as affected by rotation and nitrogen rate. I. Soybean. Agron. J. 1989, 81, 727-731. [CrossRef]

33. Peterson, T.; Varvel, G. Crop Yield as Affected by Rotation and Nitrogen Rate. II. Grain Sorghum. Agron. J. 1989, 81, 731-734. [CrossRef]

34. Peterson, T.; Varvel, G. Crop yield as affected by rotation and nitrogen rate. III. Corn. Agron. J. 1989, 81, 735-738. [CrossRef]

35. Hassink, J. Effects of soil texture and grassland management on soil organic $\mathrm{C}$ and $\mathrm{N}$ and rates of $\mathrm{C}$ and $\mathrm{N}$ mineralization. Soil Biol. Biochem. 1994, 26, 1221-1231. [CrossRef]

36. Malhi, S.; Harapiak, J.; Nyborg, M.; Flore, N. Soil chemical properties after long-term n fertilization of bromegrass: Nitrogen rate. Commun. Soil Sci. Plan. 1991, 22, 1447-1458. [CrossRef]

37. Malhi, S.; Brandt, S.; Ulrich, D.; Lemke, R.; Gill, K. Accumulation and distribution of nitrate-nitrogen and extractable phosphorus in the soil profile under various alternative cropping systems. J. Plant Nutr. 2002, 25, 2499-2520. [CrossRef]

38. Guillard, K.; Griffin, G.; Allinson, D.; Yamartino, W.; Rafey, M.; Pietrzyk, S. Nitrogen utilization of selected cropping systems in the US Northeast: II. Soil profile nitrate distribution and accumulation. Agron. J. 1995, 87, 199-207. [CrossRef]

39. Yang, X.; Zhang, S.; Yuan, X.; Tong, Y. A long-term experiment on effects of organic manure and chemical fertilization on distribution, accumulation and movement of $\mathrm{NO}_{3}{ }^{-}-\mathrm{N}$ in soil. Plant Nutr. Fertil. Sci. 2001, 7, 134-138. (In Chinese)

40. Bao, D.; Huang, S.; Huang, X.; Zhang, H. Effect of long-term fertilization on nitrate movement and distribution in Fluvo-aquic soil. In Proceedings of the 5th Cross-Strait Workshop on Soil and Fertilizer; 2004. (In Chinese)

41. Zhang, Y.; Liu, H.; Li, Z.; Lin, B.; Zhang, F. Study of nitrate leaching potential from agricultural land in Northern China under long-term fertilization conditions. Plant Nutr. Fertil. Sci. 2005, 11, 711-716. (In Chinese)

42. Cui, Z.; Zhang, F.; Miao, Y.; Sun, Q.; Li, F.; Chen, X.; Li, J.; Ye, Y.; Yang, Z.; Zhang, Q. Soil nitrate-N levels required for high yield maize production in the North China Plain. Nutr. Cycl. Agroecosyst. 2008, 82, 187-196. [CrossRef]

43. Fang, Q.; Yu, Q.; Wang, E.; Chen, Y.; Zhang, G.; Wang, J.; Li, L. Soil nitrate accumulation, leaching and crop nitrogen use as influenced by fertilization and irrigation in an intensive wheat-maize double cropping system in the North China Plain. Plant Soil 2006, 284, 335-350. [CrossRef]

44. Ju, X.; Liu, X.; Zhang, F.; Roelcke, M. Nitrogen fertilization, soil nitrate accumulation, and policy recommendations in several agricultural regions of China. AMBIO J. Hum. Environ. 2004, 33, 300-305. [CrossRef]

45. Cui, Z.; Zhang, F.; Chen, X.; Miao, Y.; Li, J.; Shi, L.; Xu, J.; Ye, Y.; Liu, C.; Yang, Z. On-farm evaluation of an in-season nitrogen management strategy based on soil Nmin test. Field Crops Res. 2008, 105, 48-55. [CrossRef]

46. Miller, G. Establishing Realistic Yield Goals; Cooperative Extension Service, Iowa State University: Ames, IA, USA, 1986.

47. Timlin, D.; Pachepsky, Y.; Snyder, V.; Bryant, R. Spatial and temporal variability of corn grain yield on a hillslope. Soil Sci. Soc. Am. J. 1998, 62, 764-773. [CrossRef]

48. Machado, S.; Bynum, E., Jr.; Archer, T.; Lascano, R.; Wilson, L.; Bordovsky, J.; Segarra, E.; Bronson, K.; Nesmith, D.; Xu, W. Spatial and temporal variability of corn grain yield: Site-specific relationships of biotic and abiotic factors. Precis. Agric. 2000, 2, 359-376. [CrossRef]

(C) 2018 by the authors. Licensee MDPI, Basel, Switzerland. This article is an open access article distributed under the terms and conditions of the Creative Commons Attribution (CC BY) license (http:/ / creativecommons.org/licenses/by/4.0/). 